\title{
Synthesis of the 26-Membered Core of Thiopeptide Natural Products by Scalable Thiazole-Forming Reactions of Cysteine Derivatives and Nitriles
}

\author{
Trevor C. Johnson ${ }^{a}$ \\ Mitchell P. Christy ${ }^{\mathrm{a}}$ \\ Dionicio Siegel ${ }^{* b}$ \\ ${ }^{\text {a }}$ Department of Chemistry \& Biochemistry, University of \\ California-San Diego, 9500 Gilman Drive, La Jolla, \\ California 92093, United States \\ b Skaggs School of Pharmacy and Pharmaceutical Sciences, \\ University of California-San Diego, 9500 Gilman Drive, \\ La Jolla, California 92093-0934, United States \\ drsiegel@health.ucsd.edu
}

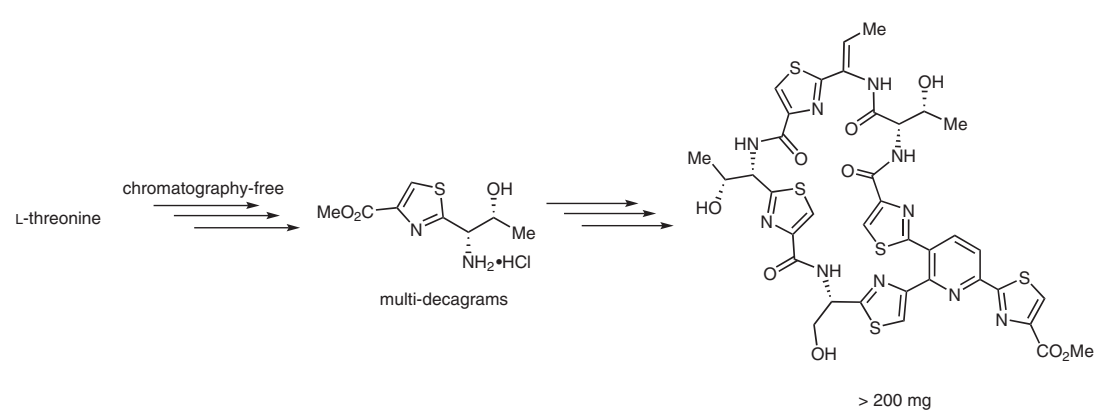

Received: 15.07.2020

Accepted after revision: 31.08 .2020

Published online: 15.10 .2020

DOI: 10.1055/s-0040-1706478; Art ID: ss-2020-z0348-fa

\begin{abstract}
The increased resistance of bacteria to clinical antibiotics is one of the major dilemmas facing human health and without solutions the problem will grow exponentially worse. Thiopeptide natural products have shown promising antibiotic activities and provide an opportunity for the development of a new class of antibiotics. Attempts to directly translate these compounds into human medicine have been limited due to poor physiochemical properties. The synthesis of the core structure of the 26-membered class of thiopeptide natural products is reported using chemistry that enables the synthesis of large quantities of synthetic intermediates and the common core structure. The use of cysteine/nitrile condensation reactions followed by oxidation to generate thiazoles has been key in enabling large academic scale reactions that in many instances avoided chromatography further aiding in accessing large amounts of key synthetic intermediates.
\end{abstract}

Key words thiopeptide, natural product, thiazole, scalable, antibiotic, pharmacophore

Resistance to clinical antibiotics has emerged as one of the major challenges confronting global health. As a result, this problem has become a top priority for international governing bodies. The Centers for Disease Control and Prevention estimates annually, in the United States, 2 million adults infected with drug-resistant bacteria and, of those infected, there is a $12 \%$ morbidity rate. ${ }^{1}$ These numbers will increase yearly. Antibiotic resistance mechanisms, many of which can be transferred between different bacteria, have greatly outpaced drug development, as a result of this disease being deprioritized by the pharmaceutical industry. Government efforts to incentivize the development of new antibiotics have been approached in large part by rejuvenating existing clinically employed antibiotics providing a lower barrier for entering the market. However, the devel- opment of new chemical entities represent a significantly better solution and is expected to have the largest impact on the current resistance dilemma.

An approach to develop a new class of antibiotics for use in humans has been inspired by the natural product nosiheptide. Nosiheptide, initially named multhiomycin, was first identified as a member of the thiazolyl peptide (thiopeptide) class of antibiotics and reported to possess potent antibiotic activity in $1970 .^{2}$ The bactericidal activity occurs through the inhibition of ribosomal protein synthesis in a manner distinct from other clinical protein synthesis inhibitors. $^{3}$ Nosiheptide has pronounced antibiotic effects against a large number of clinically relevant strains including those derived from patients. ${ }^{4}$ Potent activity is present against numerous methicillin-resistant Staphylococcus aureus (MRSA) and other multidrug resistant strains. Single digit, nanomolar activity is achieved against Clostridium difficile ( $C$. difficile), a difficult bacterium to kill. Remarkably no toxicity is seen when dosing animals at the extremely high level of $2.5 \mathrm{~g} / \mathrm{kg} .{ }^{5}$ As a result, the compounds have been used outside of the United States to increase feed conversion in livestock. ${ }^{6}$ With desirable activity and no apparent toxicity, chemistry is now needed to deliver derivatives that possess improved solubility but maintain the potent antibacterial effects. With the characterization of the potential pharmacophore of nosiheptide and related thiazolyl peptide natural products, total syntheses achieved for some of the most structurally complex members, and paths forward for development, now is the opportune time to advance this compound class through chemistry. ${ }^{7,8}$

Toward the goal of developing new derivatives the structural requirements for antibiotic activity are required. Through significant effort by multiple research groups an understanding of the pharmacophore of thiazolyl peptides 
similar to nosiheptide has been developed. Key structural similarities across this class are highlighted in red. In addition to the compounds shown in Figure 1, the related natural products thiostrepton, nocathiacins, and siomycins also possess a similar core, a 26-membered macrocycle with multiple thiazoles. Recently identified or prepared members of this class include lactocillin ${ }^{9}$ from the human microbiome (absolute configuration yet to be reported) and QN3323A (YM-266183), ${ }^{10}$ a compound undergoing development.

Important structure-activity relationships have been achieved accessing unnatural thiocillins and thiostrepton derivatives through prepeptide gene replacement. These compounds were tested for structural modifications to the antibiotics and were achieved by exchanging amino acids within the natural products precursors and determining the new, designed compounds' activity. ${ }^{11}$ Remarkably the use of prepeptide gene replacement techniques has even yielded thiocillin derivatives with variations in the size of the macrocycle, however, as expected these compounds were devoid of antibiotic activity. ${ }^{12}$ Evolved cross-resistance to the parent natural products has provided information with respect to interactions with the ribosome. ${ }^{13}$ Semisynthesis of active analogues, starting from QN3323A (YM266183), have undoubtedly built upon these findings. ${ }^{8,10}$

The total syntheses of thiazolyl peptide antibiotics have been achieved with synthetic creativity and through these studies numerous transformations have been developed and adapted. To date, arguably, the most structurally challenging thiazolyl peptide natural product to be synthesized is thiostrepton by Nicolaou and co-workers. ${ }^{14}$ The total synthesis of nosiheptide has also been achieved ${ }^{15}$ after significant efforts were made in an attempt to prepare it through total synthesis. ${ }^{16}$ In addition, many notable accomplishments have been made through the total syntheses of other thiazolyl peptide natural products. ${ }^{17}$ While a great deal of chemistry has been learned from these syntheses the application of these findings to drug development is still devel-

\section{Biographical Sketches}
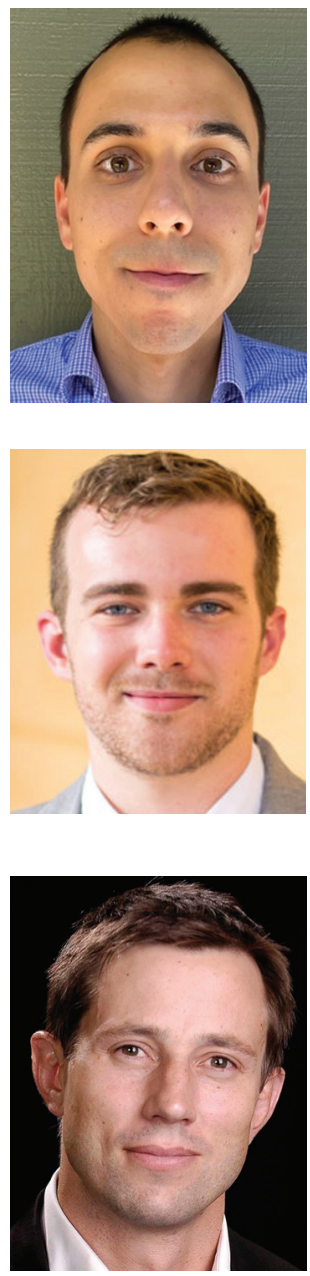

Trevor Johnson was born in Sacramento, California. He completed his undergraduate degree at the University of California, Santa Cruz in Biochemistry and Molecular Biology and completed research under the mentorship of Professor Needhi

Mitchell P. Christy was born in Houston, Texas and completed his undergraduate degree in chemistry (B.S. 2014) from the University of Texas at Austin where he undertook research in organometallic reaction method development under Dr. Guangbin Dong. He then moved to California to complete

Dionicio Siegel, born in 1974 in Truchas New Mexico, studied chemistry starting at Reed College and earned his Ph.D. in chemistry with Andy Myers at Harvard University. Postdoctoral work with Samuel Danishefsky at the Memorial Sloan-
Bhalla (Molecular Biology). He joined the labs of Professor Dionicio Siegel in 2012, where his research focused on the total synthesis of complex natural products, bioactive small molecules, and reaction methodology and he received his Ph.D. in chemistry in 2016. He joined the Process Chemistry Department at Gilead Sciences in 2016 where he is currently working on the development of innovative therapeutics for patients worldwide.

his Ph.D. in organic chemistry at UC San Diego under the direction of Dr. Dionicio Siegel where he worked on the total synthesis of natural products and drug development in the areas of malaria and cancer in collaboration with the Winzeler and Ideker labs in the school of medicine. He completed his Ph.D. in 2019

Kettering Cancer Center was followed, from 2007 to 2014, with a faculty position at The University of Texas at Austin. In 2014 he transitioned to the University of California, San Diego in the Skaggs School of Pharmacy and Pharmaceutical Sciences and is currently a postdoc in the Gerwick lab at the Scripps Institute of Oceanography in La Jolla where he is pursuing the isolation and synthesis of novel marine natural products and medicinal chemistry development of protease inhibitors against SARS-CoV-2.

where he is currently Chair of the Division of Pharmaceutical Chemistry. His research interests focus on synthetic organic chemistry applied to natural product-based drug discovery and medicinal chemistry. 


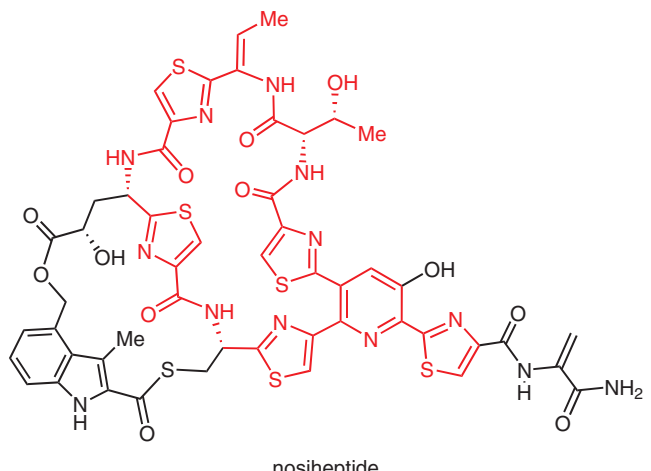

nosiheptide

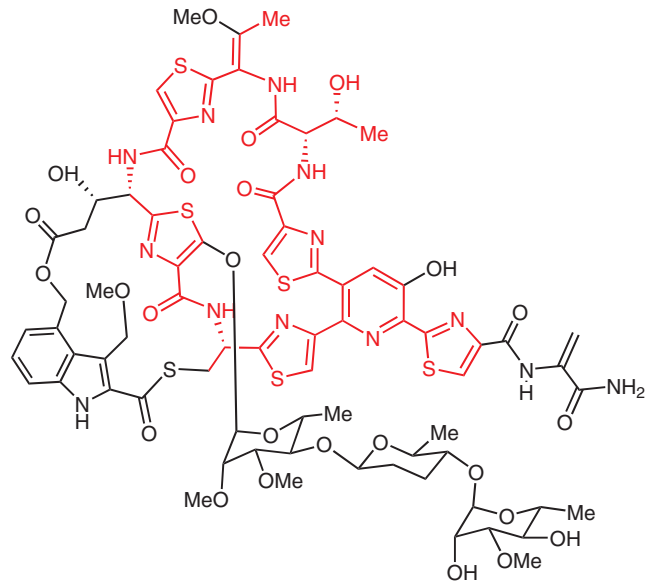

philipimycin

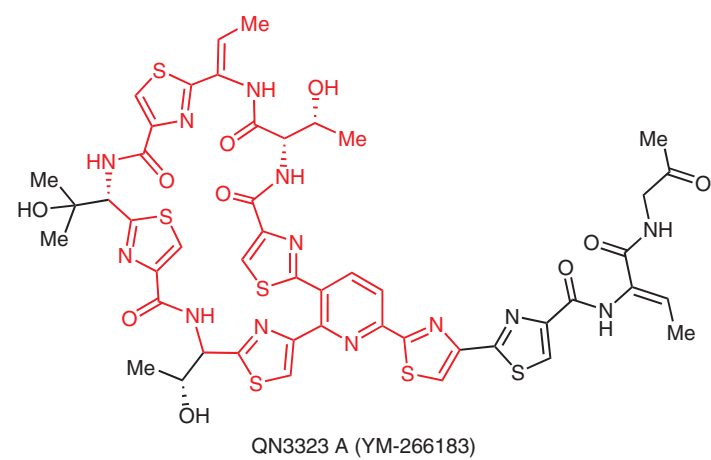

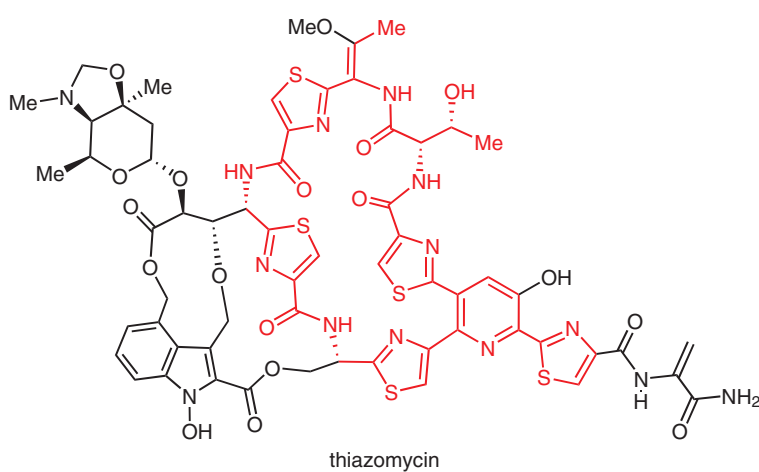<smiles>C/C=C(\NC(=O)C(NC(=O)c1csc(-c2ccc(-c3nc(-c4nc(C(=O)NC(C)C(=O)O)cs4)cs3)nc2-c2nc(C(CSC(=O)c3c[nH]c4ccccc34)NC(=O)C3CSC(C(NC(=O)c4csc(/C(=C/N)NC(C)C(C)O)n4)C(C)O)=N3)cs2)n1)C(C)O)C(=O)O</smiles>

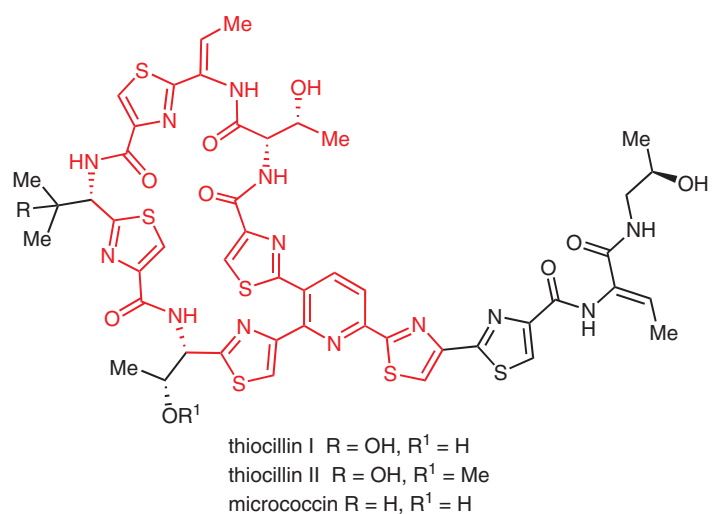

thiocillin I $\mathrm{R}=\mathrm{OH}, \mathrm{R}^{1}=\mathrm{H}$ micrococcin $\mathrm{R}=\mathrm{H}$

Figure 1 Structures of 26-membered thiazolyl peptides known or predicted to target the L11 protein/23S rRNA region of the ribosome. Related core structures are highlighted in red.

oping. In our group, we have succeeded synthesizing micrococcin P1 implementing cysteine nitrile condensation reactions to form thiazoles. ${ }^{18}$ This provided guidance in the synthesis of the common core of the 26-membered thiopeptides that we believe to be a fundamentally important substrate to assess structure-activity relationships present in this class of natural products as they are related to antiproliferative effects.
Our approach to synthesizing the fragments of thiazolyl peptides, chiral carboxyaminothiazoles, used a general strategy that has proven both reliable and scalable; cysteine-nitrile condensation reactions ${ }^{19}$ followed by aromatization. ${ }^{20}$ For comparison, the Hantzch thiazole synthesis has proven useful in the past for the syntheses of this class of natural products as the method is highly reliable, however, conducting these thiazole forming reactions on the multidecagram scale proved difficult in our hands in maintaining 
yields achieved at smaller scales. As the cysteine-nitrile condensation links easily into the syntheses of all thiazoles except for one we also utilized the addition of thiazolebased Grignard reagents into chiral $N$-sulfinylimines, which has similarly proven reliable and scalable. ${ }^{21}$

As an example, starting from threonine in a seven-step sequence that does not require chromatography we accessed 30 grams of amino alcohol $\mathbf{4}$ as its hydrochloride salt (Scheme 1). The cysteine/nitrile condensation onto nitrile $\mathbf{2}$ followed by aromatization with trichlorobromomethane and DBU was conducted on a 38 gram scale to generate pure thiazole 3 . The reaction was both clean and the product readily separated from reactants and by-products. Notably, the purification is greatly simplified compared to the Hantzch thiazole synthesis that employs Lawesson's reagent and results in the generation of poorly behaved spent reagents. Simple acidic liberation of the amino alcohol provides $\mathbf{4}$ as the hydrochloride salt with the acid masked as the methyl ester.

Coupling of the amino alcohol 4 to a compound generated earlier in the route, carboxylic acid 1, proceeded uneventfully using EDC and HOBt to generate amide 5 (Scheme 2). Dehydrative elimination to form alkene $\mathbf{6}$ on large scale failed to provide good yields under multiple conditions used for the syntheses dehydroamino acids, however, in situ formation of the tert-butyl carbonate followed by reaction with $\mathrm{DBU}$ led to facile elimination and the reaction scaled well, conducted as shown on 28 grams of material. ${ }^{22}$ Saponification of the ester of $\mathbf{6}$ generated carboxylic acid $\mathbf{7}$ that was combined with the previously synthesized amino alcohol 4 using EDC/HOBt coupling to yield amide $\mathbf{8}$. The resulting amide product $\mathbf{8}$ was then hydrolyzed at the thiazole methyl ester to yield carboxylic acid $\mathbf{9}$.

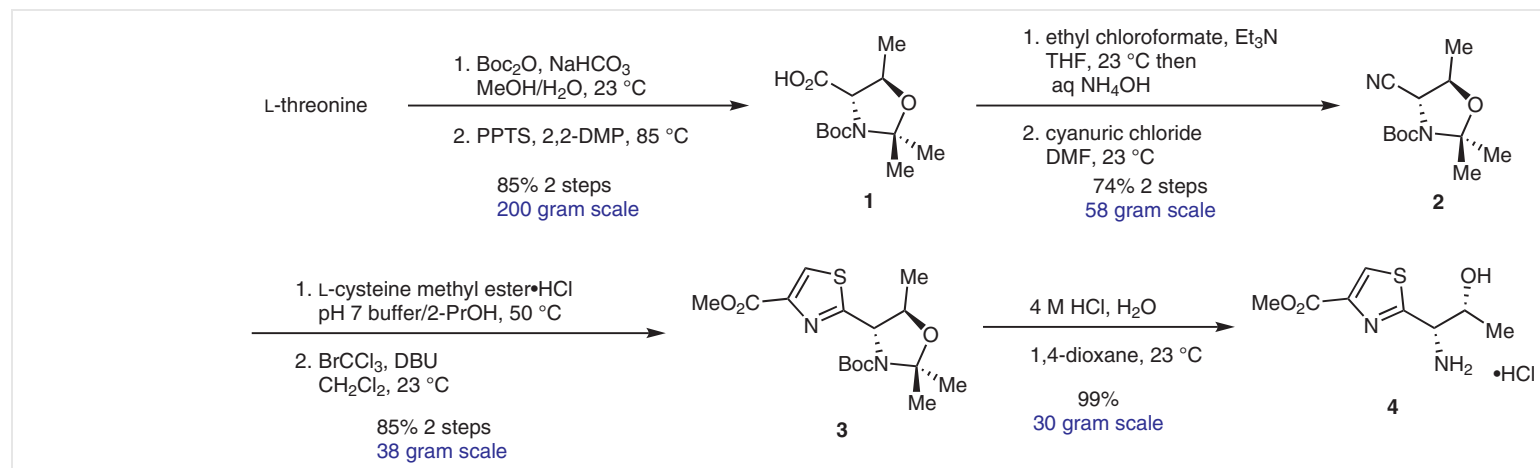

Scheme 1 Chromatography-free, multi-decagram synthesis of chiral carboxyaminothiazole 4

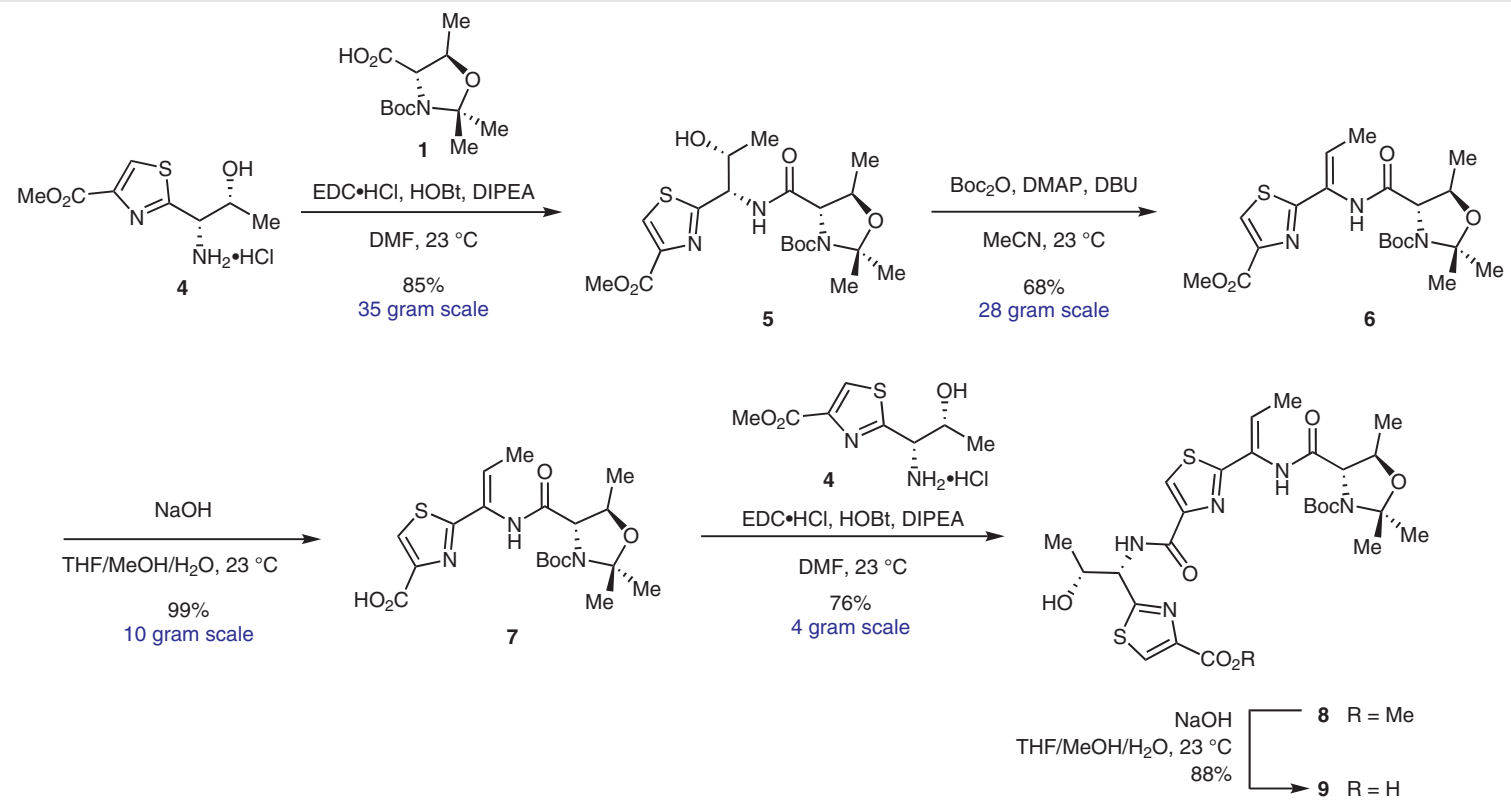

Scheme 2 Five step conversion of amino alcohol $\mathbf{4}$ into acid $\mathbf{9}$ 
Synthesis of the double thiazole-substituted pyridyl core was also greatly simplified using the cysteine/nitrile condensation-aromatization sequence (Scheme 3). Starting from inexpensive 2-chloro-3-pyridinecarbonitrile (10) seven steps arrived at the appropriately modified pyridine with the differentially protected esters, compound 14. Condensation of cysteine and 2-chloro-3-pyridinecarbonitrile (10) and oxidation of the thiazoline generated thiazole $\mathbf{1 1}$ Protection of the free acid as the tert-butyl ester and oxidation of the pyridine nitrogen to the $N$-oxide proceeded smoothly ${ }^{23}$ setting up a modified Reissert reaction with trimethylsilyl cyanide and diethylcarbamoyl chloride to provide nitrile $\mathbf{1 3}$ as a crystalline, off-white solid. The sequence was scalable with all intermediates crystallized from the reaction mixture or purified by trituration. A second cysteine/nitrile condensation followed by $\mathrm{MnO}_{2}$ oxidation (proved optimal for this system) generated the second appended thiazole ester.

The last required fragment possessed a thiazole with an alternative substitution pattern. Although a Hunsdiecker reaction could, in theory, generate this compound following a cysteine/nitrile condensation-aromatization the broad utility of the Ellman auxiliary ${ }^{21}$ led us to the route shown in Scheme 4 for the synthesis of the coupling fragment, stannane 18. Diastereoselective delivery of the Grignard derived from 2,4-dibromothiazole (Turbo Grignard exchange ${ }^{24}$ ) provided a $4: 1$ ratio of diastereomers and a $66 \%$ isolated yield of the major diastereomer.

Coupling of the three fragments chloropyridine 14, stannane 18, and acid $\mathbf{9}$ followed by macrocyclization generated the core structure triol ester 21 (Scheme 5). Stille coupling of chloropyridine 14 and stannane 18 was optimal using $\mathrm{Pd}_{2}(\mathrm{dba})_{3}$ with Cy-JohnPhos, cleanly generating the tri-thiazole bearing pyridine 19. Selective cleavage of the tert-butylsulfinyl group (and TBS) with hydrochloric acid provided an amine that was directly coupled to carboxylic acid 9 using HATU to provide the cyclization precursor in protected form, compound 20. Deprotection of both Boc groups and acetonide was followed by cyclization, again using HATU, providing the desired triol compound $\mathbf{2 1}$ in $27 \%$ yield over two steps, conducted on the gram scale.

With access to ample quantities of core compound 21, which we envision to be the key pharmacophore for the 26membered thiopeptide natural products functionalization can be achieved through modifications to the ester position and the primary alcohol. This follows from previous efforts to increase the water solubility of thiazolyl peptides, which succeeded in developing an antibiotic that reached Phase II clinical trials for the treatment of $C$. difficile, LFF571. ${ }^{25}$ The compound, developed by Norvartis, function through a
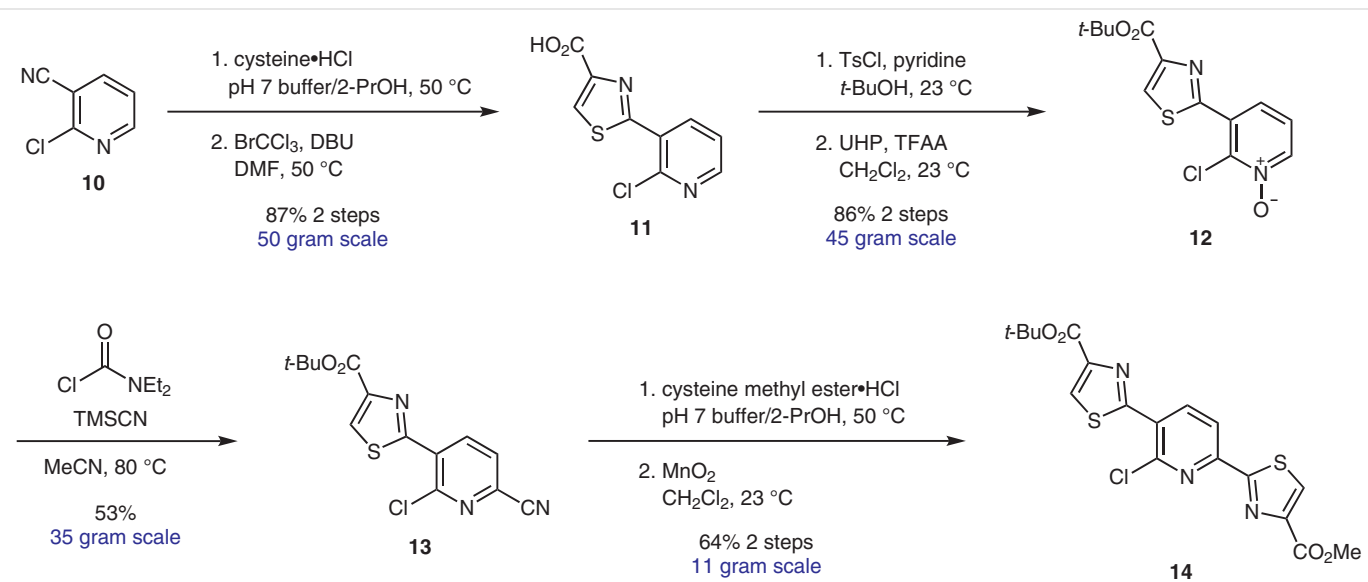

Scheme 3 Tri-substituted thiazole-pyridine 14 synthesis from commercial pyridine 10

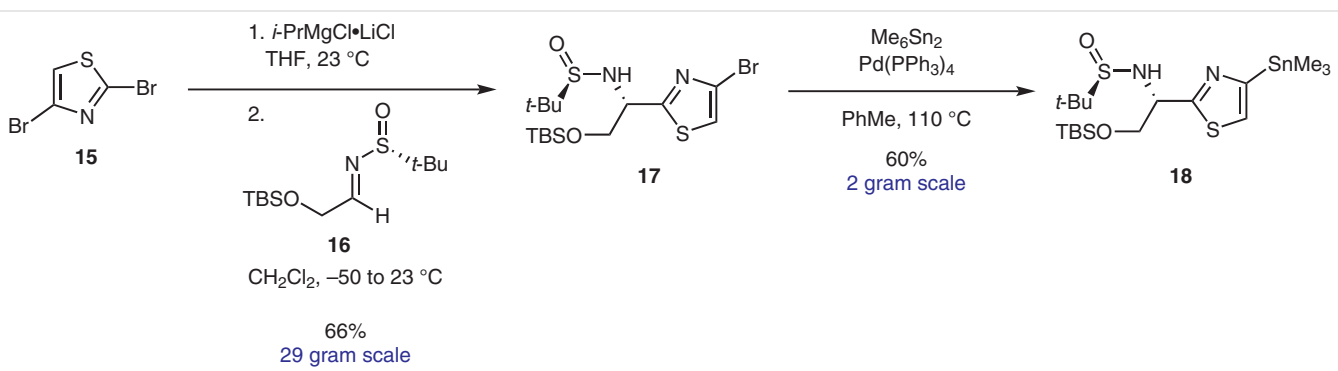

Scheme 4 Diastereoselective Grignard addition into chiral N-sulfinylimine 16 and stannylation of bromide 17 generating 18 


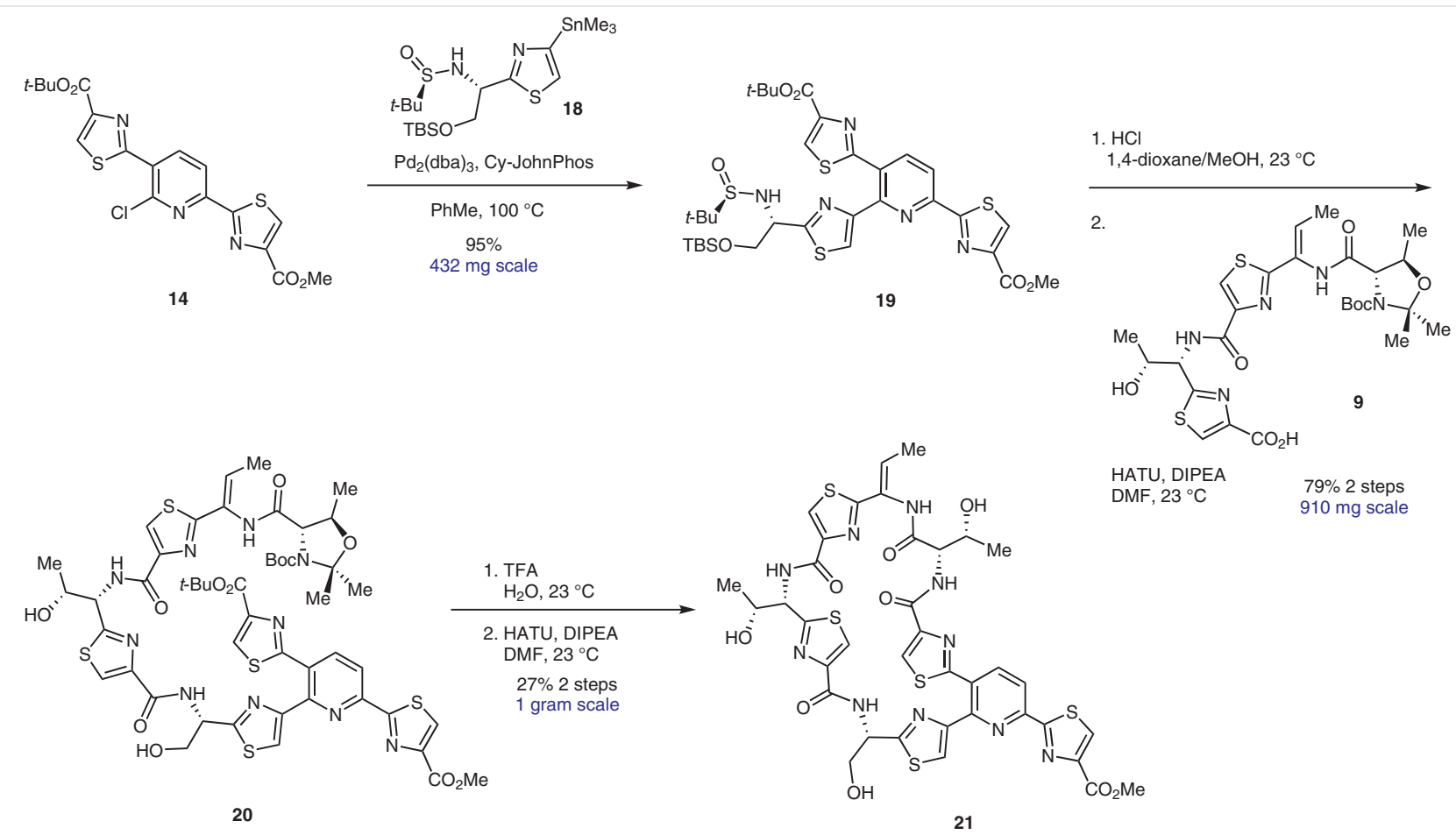

Scheme 5 Fragment coupling and completion of the synthesis of the 26-membered macrocycle 21

different mechanism of ribosome inhibition and like most of the thiazolyl peptides was initially too insoluble for development.

All reactions were performed in flame-dried round-bottomed flasks fitted with rubber septa under a positive pressure of argon or $\mathrm{N}_{2}$, unless otherwise indicated. Air and moisture sensitive liquids and solutions were transferred via syringe or cannula. Organic solutions were concentrated by rotary evaporation at 20 torr in a water bath heated to $40{ }^{\circ} \mathrm{C}$, unless otherwise noted. $\mathrm{Et}_{2} \mathrm{O}, \mathrm{CH}_{2} \mathrm{Cl}_{2}$, THF, and toluene (PhMe) were purified using a Pure-Solv MD-5 Solvent Purification System (Innovative Technology). MeCN, DMF, and $\mathrm{MeOH}$ were purchased from Acros (99.8\%, anhyd) and EtOH was purchased from Pharmco-Aaper (200 proof, absolute). The molarity of $n$-BuLi was determined by titration against diphenylacetic acid. All other reagents were used directly from the supplier without further purification, unless otherwise noted. Analytical TLC was carried out using $0.2 \mathrm{~mm}$ commercial silica gel plates (silica gel 60, F254, EMD chemical) and visualized using a UV lamp and/or aqueous ceric ammonium molybdate (CAM), aqueous $\mathrm{KMnO}_{4}$ stain, or ethanolic vanillin. IR spectra were recorded on a Nicolet 380 FTIR using neat thin film technique. High-resolution mass spectra (HRMS) were recorded on a Karatos MS9 or Agilent Technologies 6530 Accurate-Mass Q-TOF LC/MS and are reported as $m / z$ (relative intensity). Accurate masses are reported for the molecular ion $[\mathrm{M}+\mathrm{Na}]^{+},[\mathrm{M}+\mathrm{H}]^{+},[\mathrm{M}]$, or $[\mathrm{M}-\mathrm{H}] .{ }^{1} \mathrm{H}$ and ${ }^{13} \mathrm{C}$ NMR) were recorded on a Varian Gemini spectrometer [ $\left(400 \mathrm{MHz},{ }^{1} \mathrm{H}\right.$ at $400 \mathrm{MHz},{ }^{13} \mathrm{C}$ at $\left.100 \mathrm{MHz}\right),\left(500 \mathrm{MHz},{ }^{1} \mathrm{H}\right.$ at $500 \mathrm{MHz},{ }^{13} \mathrm{C}$ at 125 $\mathrm{MHz}),\left(600 \mathrm{MHz},{ }^{1} \mathrm{H}\right.$ at $600 \mathrm{MHz},{ }^{13} \mathrm{C}$ at $\left.\left.150 \mathrm{MHz}\right)\right]$. For $\mathrm{CDCl}_{3}$ solutions the chemical shifts are reported as ppm referenced to residual pro- tium or carbon of the solvent; $\mathrm{CHCl}_{3}\left(\delta_{\mathrm{H}}=7.26\right)$ and $\mathrm{CDCl}_{3}\left(\delta_{\mathrm{C}}=77.0\right)$. For DMSO- $d_{6}$ solutions the chemical shifts are reported as ppm referenced to residual protium or carbon of the solvents; $\left(\mathrm{CD}_{3}\right)\left(\mathrm{CHD}_{2}\right) \mathrm{SO}$ $\left(\delta_{\mathrm{H}}=2.50\right)$ or $\left(\mathrm{CD}_{3}\right)_{2} \mathrm{SO}\left(\delta_{\mathrm{C}}=39.5\right)$. For $\mathrm{CD}_{3} \mathrm{OD}$ solutions the chemical shifts are reported as ppm referenced to residual protium or carbon of the solvents; $\mathrm{CHD}_{2} \mathrm{OD}\left(\delta_{\mathrm{H}}=3.31\right)$ or $\mathrm{CD}_{3} \mathrm{OD}\left(\delta_{\mathrm{C}}=49.0\right)$. Coupling constants are reported in hertz $(\mathrm{Hz})$. Data for ${ }^{1} \mathrm{H}$ NMR spectra are reported as follows: chemical shift [ppm, referenced to protium; multiplicity (standard abbreviations), coupling constant ( $\mathrm{Hz})$, and integration]. Melting points were measured on a MEL-TEMP device without corrections.

\section{(4S,5R)-3-(tert-Butoxycarbonyl)-2,2,5-trimethyloxazolidine-4- carboxylic Acid (1)}

Solid L-threonine (100 g, $839 \mathrm{mmol}, 1$ equiv) was dissolved in 1.7:1 $\mathrm{THF} / 2 \mathrm{M} \mathrm{NaOH}$ and cooled in an ice bath. Boc anhydride was added as a solid portionwise $(220 \mathrm{~g}, 1.01 \mathrm{~mol}, 1.2$ equiv) over $10 \mathrm{~min}$ and the reaction mixture was stirred for $1 \mathrm{~h}$. The reaction vessel was removed from ice bath and stirred at $23{ }^{\circ} \mathrm{C}$ for $48 \mathrm{~h}$. THF was removed under vacuum, the residue taken up in aq $2 \mathrm{M} \mathrm{HCl}(2 \mathrm{~L})$, and the mixture was extracted with EtOAc $(3 \times 1 \mathrm{~L})$. The combined organic layers were washed with $\mathrm{H}_{2} \mathrm{O}(750 \mathrm{~mL})$ and brine $(750 \mathrm{~mL})$, dried $\left(\mathrm{Na}_{2} \mathrm{SO}_{4}\right)$ and concentrated to provide a colorless oil. The crude material $(175.4 \mathrm{~g})$ was used directly in the next reaction without further purification.

Crude Boc-L-threonine was dissolved in 2,2-dimethoxypropane (1.03 L) and PPTS (recrystallized from acetone) was added as a solid in one portion ( $60.3 \mathrm{~g}, 0.3$ equiv) and the reaction mixture was heated to reflux for $14 \mathrm{~h}$. The mixture was cooled to $23^{\circ} \mathrm{C}$ and then concentrated and the residue was dissolved in EtOAc $(2 \mathrm{~L})$. The EtOAc solution was washed with $\mathrm{H}_{2} \mathrm{O}(500 \mathrm{~mL})$ and brine $(500 \mathrm{~mL})$, dried $\left(\mathrm{Na}_{2} \mathrm{SO}_{4}\right)$, and 
concentrated. Recrystallization of the residue from hexanes yielded $113.1 \mathrm{~g}$ of product and an additional $58 \mathrm{~g}$ collected from a 2 nd recrystallization to provide 1 as a white solid (85\% yield over 2 steps).

${ }^{1} \mathrm{H}$ NMR $(600 \mathrm{MHz}, \mathrm{MeOD}): \delta$ (rotamers) $=4.21-4.13(\mathrm{~m}, 1 \mathrm{H}), 3.90-$ $3.80(\mathrm{~m}, 1 \mathrm{H}), 1.58$ (br s, $3 \mathrm{H}), 1.54$ (br s, $3 \mathrm{H}), 1.45$ (br d, $9 \mathrm{H}), 1.37$ (d, $J=6.1 \mathrm{~Hz}, 3 \mathrm{H})$.

\section{tert-Butyl (4R,5R)-4-Cyano-2,2,5-trimethyloxazolidine-3-carbox- ylate (2)}

Solid 1 (58 g, $224 \mathrm{mmol}, 1$ equiv) was dissolved in THF (447 mL, 0.5 $\mathrm{M})$ and cooled in an ice bath. Ethyl chloroformate $(25.8 \mathrm{~mL}, 269$ mmol, 1.2 equiv) was added followed by dropwise addition of $\mathrm{Et}_{3} \mathrm{~N}$ (37.5 mL, $269 \mathrm{mmol}, 1.2$ equiv) with vigorous stirring over $20 \mathrm{~min}$ to ensure stirring was not hindered. After the addition of ethyl chloroformate, the reaction mixture was warmed to $23^{\circ} \mathrm{C}$ and stirred for $4 \mathrm{~h}$ when full consumption of starting material was observed by TLC (ninhydrin stain). The mixture was cooled again in an ice bath and $25 \%$ aq $\mathrm{NH}_{4} \mathrm{OH}$ ( $48.8 \mathrm{~mL}, 1.4$ equiv) was added in a single portion and the mixture was stirred with slow warming over $12 \mathrm{~h}$. The solvent was removed under reduced pressure and the residue was dissolved in EtOAc (1 L). The combined extracts were washed with $\mathrm{H}_{2} \mathrm{O}(2 \times 350$ $\mathrm{mL}$ ) and brine $(350 \mathrm{~mL})$, dried $\left(\mathrm{Na}_{2} \mathrm{SO}_{4}\right)$, and concentrated to provide an amber oil ( $48.8 \mathrm{~g}$ ). This crude material was used in the next reaction without further purification.

Crude amide (51.4 g, 199 mmol, 1 equiv) was dissolved in DMF (200 $\mathrm{mL}, 1.0 \mathrm{M}$ ) and the reaction flask was immersed in a $23^{\circ} \mathrm{C}$ water bath. Solid cyanuric chloride ( $18.44 \mathrm{~g}, 100 \mathrm{mmol}, 0.5$ equiv) was added in portions over $10 \mathrm{~min}$ and stirred for $1 \mathrm{~h}$. The reaction mixture was poured slowly into ice water $(2 \mathrm{~L})$ with vigorous stirring and the solids were collected by filtration. The precipitate was washed with cold $\mathrm{H}_{2} \mathrm{O}(3 \times 250 \mathrm{~mL})$ and dried in vacuo to give the nitrile 2 as a white solid ( $35.4 \mathrm{~g}, 147 \mathrm{mmol}, 74 \%$ over two steps); $\mathrm{mp} 41-43{ }^{\circ} \mathrm{C}$.

IR (film): 2358, $1715 \mathrm{~cm}^{-1}$.

${ }^{1} \mathrm{H} \mathrm{NMR}\left(600 \mathrm{MHz}, \mathrm{CDCl}_{3}\right.$ ): $\delta=4.40$ (pent, $J=6.2 \mathrm{~Hz}, 1 \mathrm{H}$ ), $3.99(\mathrm{~m}, 1$ H), 1.59 (br s, 3 H), 1.52 (br s, 4 H), $1.48(\mathrm{~s}, 9 \mathrm{H}), 1.40$ (d, J = 6.1 Hz, 3 $\mathrm{H})$.

${ }^{13} \mathrm{C}$ NMR $\left(150 \mathrm{MHz}, \mathrm{CDCl}_{3}\right): \delta=150.4,117.1,95.7,82.0,74.1,52.9$, 28.1, 26.4, 24.4, 18.2.

HRMS (ESI): $m / z$ calcd for $\mathrm{C}_{12} \mathrm{H}_{20} \mathrm{~N}_{2} \mathrm{O}_{3} \mathrm{Na}[\mathrm{M}+\mathrm{Na}]^{+}: 263.1366$; found: 263.1366 .

\section{tert-Butyl (4S,5R)-4-[4-(Methoxycarbonyl)thiazol-2-yl]-2,2,5-} trimethyloxazolidine-3-carboxylate (3)

Nitrile 2 (37.7 g, $157 \mathrm{mmol}, 1.0$ equiv) was dissolved in a 1.5:1 mixture of $i-\mathrm{PrOH} / \mathrm{pH} 7$ phosphate buffer $(785 \mathrm{~mL}, 0.2 \mathrm{M}$ buffer, $0.1 \mathrm{M}$ concentraion) and solid cysteine methyl ester hydrochloride was added in a single portion ( $40.4 \mathrm{~g}, 236 \mathrm{mmol}, 1.5$ equiv). The reaction mixture was stirred and heated to $50{ }^{\circ} \mathrm{C}$ for $14 \mathrm{~h}$. The solvent was removed under reduced pressure and the residue was partitioned between $\mathrm{H}_{2} \mathrm{O}(1 \mathrm{~L})$ and EtOAc $(500 \mathrm{~mL})$ and the aqueous layer was extracted with EtOAc $(3 \times 250 \mathrm{~mL})$. The combined organic layers were dried $\left(\mathrm{Na}_{2} \mathrm{SO}_{4}\right)$ and concentrated to give the thiazoline $(50.9 \mathrm{~g})$ as a colorless oil that solidifies upon standing. This crude material was used directly in the next reaction without further purification.

Crude thiazoline was dissolved in DCM (475 mL, 0.3 M) and cooled in an ice bath. $\mathrm{BrCCl}_{3}$ was added ( $21 \mathrm{~mL}, 188 \mathrm{mmol}, 1.2$ equiv) followed by DBU ( $25.4 \mathrm{~mL}, 188 \mathrm{mmol}, 1.2$ equiv) dropwise over several min.
The reaction was allowed to warm to $23^{\circ} \mathrm{C}$ as the ice bath melts. After completion, the mixture was poured into aq $1 \mathrm{M} \mathrm{HCl}(500 \mathrm{~mL})$ and extracted with additional DCM $(3 \times 200 \mathrm{~mL})$. The combined organic layers were washed with $\mathrm{H}_{2} \mathrm{O}(250 \mathrm{~mL})$ and brine $(250 \mathrm{~mL})$, dried $\left(\mathrm{Na}_{2} \mathrm{SO}_{4}\right)$, and concentrated to give $47.8 \mathrm{~g}$ of thiazole 3 as an off-white solid ( $134 \mathrm{mmol}, 85 \%$ over 2 steps); mp $120-123^{\circ} \mathrm{C}$. The crude material was of sufficient purity to be used directly in the next reaction without further purification.

${ }^{1} \mathrm{H}$ NMR $\left(600 \mathrm{MHz}, \mathrm{CDCl}_{3}\right): \delta=8.17(\mathrm{br} \mathrm{s}, 1 \mathrm{H}), 4.78(\mathrm{~m}, 1 \mathrm{H}), 4.16(\mathrm{~m}$, $1 \mathrm{H}), 3.94(\mathrm{~s}, 3 \mathrm{H}), 1.69$ (br s, $6 \mathrm{H}), 1.42$ (br s, 9 H), 1.18 (br s, $3 \mathrm{H})$.

${ }^{13} \mathrm{C}$ NMR $\left(150 \mathrm{MHz}, \mathrm{CDCl}_{3}\right): \delta=173.3,161.3,151.0,146.1,127.3,95.0$, 80.4, 77.6, 65.7, 52.1, 27.8, 26.2, 25.6, 17.6.

HRMS (ESI): $m / z$ calcd for $\mathrm{C}_{16} \mathrm{H}_{24} \mathrm{~N}_{2} \mathrm{O}_{5} \mathrm{SNa}$ [M $\left.+\mathrm{Na}\right]^{+}:$379.1298; found: 379.1295 .

\section{Methyl 2-[(1S,2R)-1-Amino-2-hydroxypropyl]thiazole-4-carboxyl-} ate Hydrochloride (4)

1,4-Dioxane ( $1 \mathrm{~mL} / \mathrm{g}$ ) was added to thiazole 3 (30 g, $84 \mathrm{mmol}, 1$ equiv) to solubilize the material. A $4 \mathrm{M}$ solution of $\mathrm{HCl}$ in 1,4-dioxane was added ( $105 \mathrm{~mL}, 5$ equiv) followed by dropwise addition of distilled $\mathrm{H}_{2} \mathrm{O}(11 \mathrm{~mL}, 10 \% \mathrm{v} / \mathrm{v})$. The reaction mixture was stirred at $23{ }^{\circ} \mathrm{C}$ for 2 h. An oil or solid might appear to precipitate from the reaction, which was the desired $\mathrm{HCl}$ salt. The mixture was concentrated from $4: 1$ benzene/MeOH $(3 \times 100 \mathrm{~mL})$. The solid crude material was of sufficient purity to be used directly in the next reaction without further purification (99\%).

${ }^{1} \mathrm{H}$ NMR $(600 \mathrm{MHz}, \mathrm{MeOD}): \delta=8.54(\mathrm{~s}, 1 \mathrm{H}), 4.88(\mathrm{~s}, 1 \mathrm{H}), 4.76(\mathrm{~d}, J=$ $6.6 \mathrm{~Hz}, 1 \mathrm{H}), 4.32-4.26(\mathrm{~m}, 1 \mathrm{H}), 3.92(\mathrm{~s}, 3 \mathrm{H}), 1.23(\mathrm{~d}, J=6.4 \mathrm{~Hz}, 3 \mathrm{H})$.

${ }^{13} \mathrm{C}$ NMR (150 MHz, MeOD): $\delta=165.2,162.9,147.3,131.7,68.5,58.8$, 53.0, 19.9.

HRMS (ESI): $m / z$ calcd for $\mathrm{C}_{16} \mathrm{H}_{24} \mathrm{~N}_{2} \mathrm{O}_{5} \mathrm{SNa}[\mathrm{M}+\mathrm{Na}]^{+}: 239.0461$; found: 239.0463 .

tert-Butyl (4S,5R)-4-(\{(1S,2R)-2-Hydroxy-1-[4-(methoxycarbonyl)thiazol-2-yl]propyl\}carbamoyl)-2,2,5-trimethyloxazolidine-3carboxylate (5)

Amine 4 (35.3 g, $140 \mathrm{mmol}, 1$ equiv) was dissolved in DMF ( $280 \mathrm{~mL}$, $0.5 \mathrm{M}$ ) along with protected threonine $1(39.9 \mathrm{~g}, 154 \mathrm{mmol}, 1.1$ equiv), EDC hydrochloride ( $32.2 \mathrm{~g}, 168 \mathrm{mmol}, 1.2$ equiv), and $\mathrm{HOBt}$ (22.7 g, $168 \mathrm{mmol}, 1.2$ equiv, 80\% w/w). DIPEA was added dropwise over $5 \mathrm{~min}$ ( $73 \mathrm{~mL}, 420 \mathrm{mmol}, 3$ equiv) and the reaction mixture was stirred to completion at $23{ }^{\circ} \mathrm{C}$ for $14 \mathrm{~h}$. The mixture was diluted with $\mathrm{H}_{2} \mathrm{O}(2 \mathrm{~L})$ and extracted with EtOAc $(3 \times 500 \mathrm{~mL})$. The combined organic layers were washed with aq $3 \mathrm{M} \mathrm{LiCl}(3 \times 300 \mathrm{~mL})$, dried $\left(\mathrm{Na}_{2} \mathrm{SO}_{4}\right)$, and concentrated. The crude material was purified by column chromatography with $60 \rightarrow 80 \%$ EtOAc/hexane on a short length column; the desired product $\mathbf{5}$ was collected pure after chromatography (54.5 g, $119 \mathrm{mmol}, 85 \%)$; white foam.

${ }^{1} \mathrm{H} \mathrm{NMR}\left(600 \mathrm{MHz}, \mathrm{CDCl}_{3}\right): \delta=7.98$ (s, $\left.1 \mathrm{H}\right), 5.15$ (br s, $\left.1 \mathrm{H}\right), 4.44$ (m, 1 H), 4.13 (br s, $1 \mathrm{H}$ ), 3.82 (d, J = 7.4 Hz, $1 \mathrm{H}), 3.76(\mathrm{~s}, 3 \mathrm{H}), 1.48(\mathrm{~s}, 3 \mathrm{H})$, $1.46(\mathrm{~s}, 3 \mathrm{H}), 1.26$ (br s, $9 \mathrm{H}), 1.15(\mathrm{~d}, J=6.5 \mathrm{~Hz}, 3 \mathrm{H})$.

${ }^{13} \mathrm{C}$ NMR $\left(150 \mathrm{MHz}, \mathrm{CDCl}_{3}\right): \delta=171.1,170.1,161.2,151.9,145.9$, 127.6, 94.5, 80.7, 73.7, 68.7, 67.1, 55.8, 52.0, 28.0, 27.4, 25.1, 19.3, 18.7 .

HRMS (ESI): $m / z$ calcd for $\mathrm{C}_{20} \mathrm{H}_{31} \mathrm{~N}_{3} \mathrm{O}_{7} \mathrm{SNa}[\mathrm{M}+\mathrm{Na}]^{+}: 480.1775$; found: 480.1778 . 
tert-Butyl (4S,5R)-4-(\{(Z)-1-[4-(Methoxycarbonyl)thiazol2-yl]prop-1-en-1-yl\}carbamoyl)-2,2,5-trimethyloxazolidine3-carboxylate (6)

Solid 5 (28.1 g, 61.4 mmol, 1 equiv) was dissolved in MeCN (205 mL, $0.3 \mathrm{M}$ ). Boc anhydride (16.1 g, $73.7 \mathrm{mmol}, 1.2$ equiv) was added in a single portion followed by DMAP ( $1.5 \mathrm{~g}, 12.3 \mathrm{mmol}, 0.2$ equiv) and the reaction mixture was stirred until all starting materials were consumed. After full conversion of starting materials by TLC, DBU ( 45.8 $\mathrm{mL}, 307.0 \mathrm{mmol}, 5$ equiv) was added dropwise at $23^{\circ} \mathrm{C}$ and the mixture was stirred for $14 \mathrm{~h}$. The mixture was diluted with EtOAc (500 $\mathrm{mL})$ and washed with aq $1 \mathrm{M} \mathrm{HCl}(200 \mathrm{~mL}), \mathrm{H}_{2} \mathrm{O}(200 \mathrm{~mL})$ and brine $(200 \mathrm{~mL})$, dried $\left(\mathrm{Na}_{2} \mathrm{SO}_{4}\right)$, and concentrated. The crude material was purified by column chromatography with $15 \rightarrow 35 \%$ EtOAc/hexane on a medium length column to give $18.38 \mathrm{~g}$ of intermediate $\mathbf{6}$ as a colorless oil (41.8 mmol, 68\%).

$\left.{ }^{1} \mathrm{H} \mathrm{NMR} \mathrm{(600} \mathrm{MHz,} \mathrm{CDCl}_{3}\right): \delta=7.99(\mathrm{~s}, 1 \mathrm{H}), 7.96$ (br s, $\left.1 \mathrm{H}\right), 6.54$ (br s, $1 \mathrm{H}$ ), 4.32 (br s, $1 \mathrm{H}), 3.97$ (d, $J=7.7 \mathrm{~Hz}, 1 \mathrm{H}), 3.85$ (s, $3 \mathrm{H}), 1.82$ (d, $J=$ $6.6 \mathrm{~Hz}, 3 \mathrm{H}), 1.61$ (br s, $6 \mathrm{H}), 1.44(\mathrm{~d}, J=6.1 \mathrm{~Hz}, 3 \mathrm{H}), 1.40(\mathrm{~s}, 9 \mathrm{H})$.

${ }^{13} \mathrm{C}$ NMR $\left(150 \mathrm{MHz}, \mathrm{CDCl}_{3}\right): \delta=168.4,167.3,161.7,152.3,146.7$, 127.9, 127.1, 95.1, 81.1, 74.2, 67.8, 52.3, 28.3, 27.7, 25.5, 19.0, 14.4.

HRMS $(E S I)^{+}: m / z$ calcd for $\mathrm{C}_{20} \mathrm{H}_{29} \mathrm{~N}_{3} \mathrm{O}_{6} \mathrm{SNa}[\mathrm{M}+\mathrm{Na}]^{+}: 462.1669$; found: 462.1665 .

tert-Butyl (4S,5R)-4-(\{(Z)-1-[4-(\{(1S,2R)-2-Hydroxy-1-[4-(methoxycarbonyl)thiazol-2-yl]propyl\}carbamoyl)thiazol-2-yl]prop-1en-1-yl\}carbamoyl)-2,2,5-trimethyloxazolidine-3-carboxylate (8) Methyl ester 6 ( $10.0 \mathrm{~g}, 22.8 \mathrm{mmol}, 1$ equiv) was dissolved in a mixture of 3:1 THF and $\mathrm{MeOH}(11.4 \mathrm{~mL}, 0.2 \mathrm{M}$ ) and aq $10 \% \mathrm{NaOH}$ was added (22.8 mL, $2.28 \mathrm{~g}, 2.5$ equiv). The reaction mixture was stirred for $1 \mathrm{~h}$ and poured into aq $2 \mathrm{M} \mathrm{HCl}(100 \mathrm{~mL})$, extracted with EtOAc $(3 \times 50$ $\mathrm{mL})$; the combined organic layers were dried $\left(\mathrm{Na}_{2} \mathrm{SO}_{4}\right)$ and concentrated. The crude acid $\mathbf{7}$ (clear oil was used directly in the next reaction without further purification (99\%).

Crude acid 7 ( $3.83 \mathrm{~g}, 9.0 \mathrm{mmol}, 1$ equiv) was dissolved in DMF (45 mL, $0.2 \mathrm{M}$ ) and solid amine hydrochloride 4 was added ( $2.50 \mathrm{~g}, 9.9 \mathrm{mmol}$, 1.1 equiv) followed by HATU ( $2.07 \mathrm{~g}, 10.8 \mathrm{mmol}, 1.2$ equiv). Neat DIPEA was added dropwise ( $7.84 \mathrm{~mL}, 45.0 \mathrm{mmol}, 5$ equiv) and the reaction mixture was stirred for $12 \mathrm{~h}$. The mixture was poured into brine $(500 \mathrm{~mL})$ and extracted with EtOAc $(3 \times 125 \mathrm{~mL})$. The combined organic layers were washed with aq $3 \mathrm{M} \mathrm{LiCl}(3 \times 100 \mathrm{~mL})$, dried $\left(\mathrm{Na}_{2} \mathrm{SO}_{4}\right)$, and concentrated. The crude material was purified by column chromatography with $55 \rightarrow 75 \%$ EtOAc/hexane on a medium length column to give $4.25 \mathrm{~g}$ of 8 as a white solid (6.81 mmol, 76\% over 2 steps).

${ }^{1} \mathrm{H}$ NMR (600 MHz, MeOD): $\delta$ (rotamers) $=8.34(\mathrm{~s}, 1 \mathrm{H}), 8.19(\mathrm{~s}, 1 \mathrm{H})$, 6.89-6.53 (m, $1 \mathrm{H}), 5.34(\mathrm{~s}, 1 \mathrm{H}), 4.53(\mathrm{~s}, 1 \mathrm{H}), 4.25(\mathrm{~s}, 1 \mathrm{H}), 4.12-4.03$ $(\mathrm{m}, 1 \mathrm{H}), 3.92(\mathrm{~s}, 3 \mathrm{H}), 1.91(\mathrm{dd}, J=6.8,2.2 \mathrm{~Hz}, 3 \mathrm{H}), 1.59-1.26(\mathrm{~m}, 21$ $\mathrm{H})$.

2-[(1S,2R)-1-(2-\{(Z)-1-[(4S,5R)-3-(tert-Butoxycarbonyl)-2,2,5trimethyloxazolidine-4-carboxamido]prop-1-en-1-yl $\}$ thiazole-4carboxamido)-2-hydroxypropyl]thiazole-4-carboxylic Acid (9)

Methyl ester 8 (462 mg, $1.17 \mathrm{mmol}, 1$ equiv) was dissolved in a 3:1 mixture of THF and $\mathrm{MeOH}(7.5 \mathrm{~mL})$ and aq $2 \mathrm{M} \mathrm{NaOH}$ was added $(0.74$ $\mathrm{mL}, 2.93 \mathrm{mmol}, 2.5$ equiv) and the reaction mixture was stirred for 1 h. After full conversion of starting material, the mixture was acidified with aq $2 \mathrm{M} \mathrm{HCl}(40 \mathrm{~mL})$ and extracted with EtOAc $(3 \times 25 \mathrm{~mL})$. The combined organic layers were dried $\left(\mathrm{Na}_{2} \mathrm{SO}_{4}\right)$ and concentrated to give the carboxylic acid $\mathbf{9}$ as a white solid. This crude material was analytically pure and was used in the next reaction without further purification (>99\%).

${ }^{1} \mathrm{H}$ NMR (600 MHz, MeOD): $\delta=8.30$ (s, $\left.1 \mathrm{H}\right), 8.19$ (s, $\left.1 \mathrm{H}\right), 6.88-6.54$ (m, $1 \mathrm{H}), 5.35$ (br s, $1 \mathrm{H}), 4.55$ (br s, $1 \mathrm{H}), 4.27-4.22(\mathrm{~m}, 1 \mathrm{H}), 4.05$ (d, $J=8.0 \mathrm{~Hz}, 1 \mathrm{H}), 1.91$ (d, $J=7.2 \mathrm{~Hz}, 3 \mathrm{H}), 1.59-1.39(\mathrm{~m}, 18 \mathrm{H}), 1.28$ (d, $J=6.4 \mathrm{~Hz}, 3 \mathrm{H}$ ).

\section{2-(2-Chloropyridin-3-yl)thiazole-4-carboxylic Acid (11)}

2-Chloronicotinonitrile (10; $50 \mathrm{~g}, 361 \mathrm{mmol}, 1$ equiv) was dissolved in $1.5: 1 i-\mathrm{PrOH} / \mathrm{pH} 7$ phosphate buffer $(722 \mathrm{~mL}, 0.5 \mathrm{M})$ and solid Lcysteine hydrochloride ( $65.6 \mathrm{~g}, 542 \mathrm{mmol}, 1.5$ equiv) was added in one portion. The reaction mixture was heated to $50{ }^{\circ} \mathrm{C}$ and stirred for $16 \mathrm{~h}$. The reaction was then terminated by removing $i$-PrOH under reduced pressure and diluting with EtOAc $(500 \mathrm{~mL})$ and aq $2 \mathrm{M} \mathrm{HCl}$ until the solution was acidic $(\mathrm{pH}>2)$. The mixture was extracted with EtOAc $(3 \times 400 \mathrm{~mL})$, the combined extracts were dried $\left(\mathrm{Na}_{2} \mathrm{SO}_{4}\right)$, and concentrated to give the intermediate thiazoline as a yellow solid (76.9 g, $317 \mathrm{mmol}, 88 \%$ ); mp $156-158^{\circ} \mathrm{C}$. The crude material was of sufficient purity to be used directly in the next reaction without further purification.

${ }^{1} \mathrm{H}$ NMR (600 MHz, MeOD): $\delta=8.49$ (dd, $J=4.9,1.8 \mathrm{~Hz}, 1 \mathrm{H}$ ), 8.10 (dd, $J=7.7,1.8 \mathrm{~Hz}, 1 \mathrm{H}), 7.49(\mathrm{dd}, J=7.7,4.9 \mathrm{~Hz}, 1 \mathrm{H}), 5.36(\mathrm{t}, J=9.2 \mathrm{~Hz}, 1$ $\mathrm{H}), 3.87-3.80$ ( $\mathrm{m}, 2 \mathrm{H})$.

Crude thiazoline ( $76.9 \mathrm{~g}, 317 \mathrm{mmol}, 1$ equiv) and $\mathrm{BrCCl}_{3}$ (46.9 mL, 476 mmol, 1.5 equiv) were dissolved in $\operatorname{DMF}(317 \mathrm{~mL}, 1 \mathrm{M})$ in a flask and the flask was immersed in an ice bath. DBU $(99 \mathrm{~mL}, 666 \mathrm{mmol}, 2.1$ equiv) was added dropwise via an addition funnel over $20 \mathrm{~min}$. On large scale this addition was significantly exothermic. After addition, the reaction mixture was then brought to $50{ }^{\circ} \mathrm{C}$ and stirred for $3 \mathrm{~h}$. After completion, the mixture was slowly introduced dropwise into a vigorously stirring aq $1 \mathrm{M} \mathrm{HCl}(2 \mathrm{~L})$ at $0{ }^{\circ} \mathrm{C}$ to ensure a uniform precipitate. The mixture was stirred for $10 \mathrm{~min}$ and the fine brown precipitate was filtered and dried under vacuum at $50{ }^{\circ} \mathrm{C}$ for $18 \mathrm{~h}$ to give 76.0 $\mathrm{g}(99 \%, 87 \%$ over 2 steps) of crude thiazole product 11 as a grey-brown solid; $\mathrm{mp}>200{ }^{\circ} \mathrm{C}$. The crude material was of sufficient purity to be used directly in the next reaction without further purification.

${ }^{1} \mathrm{H}$ NMR (600 MHz, MeOD): $\delta=8.76$ (dd, $J=7.9,1.8 \mathrm{~Hz}, 1 \mathrm{H}$ ), 8.58 (s, 1 $\mathrm{H}), 8.50(\mathrm{dd}, J=4.7,1.9 \mathrm{~Hz}, 1 \mathrm{H}), 7.58(\mathrm{dd}, J=7.9,4.7 \mathrm{~Hz}, 1 \mathrm{H})$.

${ }^{13} \mathrm{C}$ NMR $\left(150 \mathrm{MHz}\right.$, DMSO- $\left.d_{6}\right): \delta=162.4,161.6,151.3,148.0,147.6$, 140.2, 131.1, 128.3, 124.4.

HRMS (ESI): $m / z$ calcd for $\mathrm{C}_{9} \mathrm{H}_{5} \mathrm{ClN}_{2} \mathrm{O}_{2} \mathrm{~S}[\mathrm{M}-\mathrm{H}]^{-}: 238.9687$; found: 238.9689 .

\section{3-[4-(tert-Butoxycarbonyl)thiazol-2-yl]-2-chloropyridine 1-0xide} (12)

Thiazolyl pyridine $\mathbf{1 1}$ ( $45.4 \mathrm{~g}, 189 \mathrm{mmol}, 1$ equiv) was dissolved in 3:1 $t$-BuOH/pyridine (756 mL, $0.25 \mathrm{M})$. TsCl (71.9 g, 2 equiv) was added slowly at $23^{\circ} \mathrm{C}$ and the reaction mixture was then stirred at $60{ }^{\circ} \mathrm{C}$ for $4 \mathrm{~h}$. The mixture was slowly poured into vigorously stirring distilled $\mathrm{H}_{2} \mathrm{O}(3 \mathrm{~L})$ and stirred for $10 \mathrm{~min}$. The precipitate was filtered, washed with cold distilled $\mathrm{H}_{2} \mathrm{O}(2 \times 500 \mathrm{~mL})$, and dried on the filter for $4 \mathrm{~h}$ to give the $t$-Bu ester as a brown solid (51.83 g, 93\%); mp $115-117^{\circ} \mathrm{C}$.

Crude $t$-Bu ester (10.36 g, 34.9 mmol, 1 equiv) and urea- $\mathrm{H}_{2} \mathrm{O}_{2}$ complex (6.57 g, $69.8 \mathrm{mmol}, 2$ equiv) were dissolved in anhyd DCM (175 $\mathrm{mL}, 0.2 \mathrm{M}$ ) in a flame-dried flask equipped with a stir bar. Trifluoroacetic anhydride (TFAA; $9.71 \mathrm{~mL}, 69.8 \mathrm{mmol}, 2$ equiv) was added dropwise over $30 \mathrm{~min}$ via an addition funnel to the reaction mixture 
in an ice bath. The mixture was then warmed to $23{ }^{\circ} \mathrm{C}$ and stirred to completion over $12 \mathrm{~h}$. After completion, the reaction was diluted with additional DCM $(175 \mathrm{~mL})$ and aq $10 \% \mathrm{~K}_{2} \mathrm{CO}_{3}(175 \mathrm{~mL})$. The organic layer was washed with $\mathrm{H}_{2} \mathrm{O}(2 \times 100 \mathrm{~mL})$, sat. aq $\mathrm{Na}_{2} \mathrm{~S}_{2} \mathrm{O}_{3}(2 \times 100 \mathrm{~mL})$ and brine $(100 \mathrm{~mL})$, dried $\left(\mathrm{Na}_{2} \mathrm{SO}_{4}\right)$, and concentrated to give $10.1 \mathrm{~g}$ of crude $\mathrm{N}$-oxide as a yellow solid ( $32.1 \mathrm{mmol}, 92 \%$; $86 \%$ over 2 steps); $\mathrm{mp} 134-136^{\circ} \mathrm{C}$. The crude material was of sufficient purity to be used directly in the next reaction without further purification.

${ }^{1} \mathrm{H}$ NMR (599 MHz, MeOD): $\delta=8.61(\mathrm{dd}, J=6.5,1.4 \mathrm{~Hz}, 1 \mathrm{H}), 8.56(\mathrm{~s}, 1$ $\mathrm{H}), 8.36(\mathrm{dd}, J=8.2,1.4 \mathrm{~Hz}, 1 \mathrm{H}), 7.60(\mathrm{dd}, J=8.2,6.5 \mathrm{~Hz}, 1 \mathrm{H}), 1.63$ (s, $9 \mathrm{H})$.

${ }^{13} \mathrm{C}$ NMR $\left(150 \mathrm{MHz}, \mathrm{CDCl}_{3}\right): \delta=160.0,159.9,148.8,140.4,131.6$, 128.8, 126.8, 122.9, 82.6, 28.1.

HRMS (ESI): $m / z$ calcd for $\mathrm{C}_{14} \mathrm{H}_{12} \mathrm{ClN}_{3} \mathrm{O}_{2} \mathrm{~S}[\mathrm{M}+\mathrm{Na}]^{+}: 335.0228$; found: 335.0221 .

\section{tert-Butyl 2-(2-Chloro-6-cyanopyridin-3-yl)thiazole-4-carboxyl- ate (13)}

The $N$-oxide 12 ( $35.1 \mathrm{~g}, 112 \mathrm{mmol}, 1$ equiv) was dissolved in anhyd MeCN (374 mL, $0.3 \mathrm{M}$ ) and TMSCN (35.1 mL, 2.5 equiv) and diethylcarbamyl chloride $\left(35.6 \mathrm{~mL}, 2.5\right.$ equiv) were added at $23^{\circ} \mathrm{C}$. The reaction mixture was then brought to reflux and stirred for $14 \mathrm{~h}$ to completion. The reaction mixture was slowly poured into a vigorously stirred ice cold solution of aq $10 \% \mathrm{~K}_{2} \mathrm{CO}_{3}(1.5 \mathrm{~L})$ and stirred for 10 min. The brown precipitate was filtered and washed with additional cold $\mathrm{H}_{2} \mathrm{O}(3 \times 200 \mathrm{~mL})$. The collected solids were dissolved in EtOAc $(500$ $\mathrm{mL})$, washed with brine $(300 \mathrm{~mL})$, dried $\left(\mathrm{Na}_{2} \mathrm{SO}_{4}\right)$, and concentrated. The crude product was recrystallized from hexanes and EtOAc to give $19.13 \mathrm{~g}$ of 13 as a crystalline, slightly yellow solid. (59.5 mmol; 53\%); mp $151-154^{\circ} \mathrm{C}$.

${ }^{1} \mathrm{H} \mathrm{NMR}\left(600 \mathrm{MHz}, \mathrm{CDCl}_{3}\right): \delta=9.01(\mathrm{~d}, J=8.0 \mathrm{~Hz}, 1 \mathrm{H}), 8.30(\mathrm{~s}, 1 \mathrm{H})$, $7.78(\mathrm{~d}, J=8.0 \mathrm{~Hz}, 1 \mathrm{H}), 1.64(\mathrm{~s}, 9 \mathrm{H})$.

${ }^{13} \mathrm{C}$ NMR $\left(150 \mathrm{MHz}, \mathrm{CDCl}_{3}\right): \delta=160.0,159.6,149.2,148.7,140.4$, 133.0, 131.6, 129.4, 127.2, 115.6, 82.8, 28.2.

HRMS (ESI): $m / z$ calcd for $\mathrm{C}_{14} \mathrm{H}_{12} \mathrm{ClN}_{3} \mathrm{O}_{2} \mathrm{SNa}[\mathrm{M}+\mathrm{Na}]^{+}: 344.0231$; found: 344.0227 .

\section{tert-Butyl 2-\{2-Chloro-6-[4-(methoxycarbonyl)thiazol-2-yl]- pyridin-3-yl\}thiazole-4-carboxylate (14)}

Cyanopyridine 13 (10.94 g, 34.0 mmol, 1 equiv) was dissolved in 1.5:1 $i-\mathrm{PrOH} / \mathrm{pH} 7$ phosphate buffer ( $340 \mathrm{~mL}, 0.2 \mathrm{M}$ buffer, $0.1 \mathrm{M}$ reaction) followed by solid cysteine methyl ester hydrochloride (8.75 g, 51 mmol, 1.5 equiv) in one portion. The reaction mixture was heated to $50{ }^{\circ} \mathrm{C}$ and stirred for $6 \mathrm{~h}$. $i$-PrOH was removed under reduced pressure and the residue was diluted with $\mathrm{H}_{2} \mathrm{O}(300 \mathrm{~mL})$ and this mixture was extracted with EtOAc $(3 \times 100 \mathrm{~mL})$. The combined organic layers were washed with brine $(100 \mathrm{~mL})$, dried $\left(\mathrm{Na}_{2} \mathrm{SO}_{4}\right)$, and concentrated to give $7.2 \mathrm{~g}$ of crude thiazoline as a yellow solid $(9.18 \mathrm{mmol}, 65 \%)$. The crude material was used directly in the next reaction without further purification.

Crude thiazoline (7.2 g, $22.2 \mathrm{mmol}, 1$ equiv) was dissolved in anhyd DCM (222 mL, $0.1 \mathrm{M}$ ) and activated $\mathrm{MnO}_{2}$ (42.4 g, $444 \mathrm{mmol}, 20$ equiv) was added (Alfa Aesar; tech. 90\%; LOT: W08D050). The reaction mixture was stirred rapidly for $18 \mathrm{~h}$, then filtered through a pad of silica gel with $\mathrm{MeOH}$ to give the desired product as a yellow solid (>99\%, $64 \%$ over 2 steps); $\mathrm{mp}>200{ }^{\circ} \mathrm{C}$. The crude material was of sufficient purity to be used directly in the next reaction without further purification.
${ }^{1} \mathrm{H}$ NMR $\left(600 \mathrm{MHz}, \mathrm{CDCl}_{3}\right): \delta=8.97(\mathrm{~d}, J=8.2 \mathrm{~Hz}, 1 \mathrm{H}), 8.38(\mathrm{~d}, J=8.2$ $\mathrm{Hz}, 1 \mathrm{H}), 8.35$ (s, $1 \mathrm{H}), 8.24$ (s, $1 \mathrm{H}), 4.01$ (s, $3 \mathrm{H}), 1.64$ (s, $9 \mathrm{H})$.

${ }^{13} \mathrm{C}$ NMR $\left(150 \mathrm{MHz}, \mathrm{CDCl}_{3}\right): \delta=167.1,161.6,161.0,160.2,150.7$, 148.3, 147.4, 140.8, 130.7, 129.1, 128.5, 119.1, 82.4, 52.6, 28.1.

HRMS (ESI): $m / z$ calcd for $\mathrm{C}_{18} \mathrm{H}_{16} \mathrm{ClN}_{3} \mathrm{O}_{4} \mathrm{~S}_{2} \mathrm{Na}[\mathrm{M}+\mathrm{Na}]^{+}: 438.0344$; found: 438.0346 .

\section{$(R)-N-\{(S)-1-(4-B r o m o t h i a z o l-2-y l)-2-[($ tert-butyldimethyl-} silyl)oxy]ethyl\}-2-methylpropane-2-sulfinamide (17)

Solid 2,4-dibromothiazole 15 ( $28.9 \mathrm{~g}, 119 \mathrm{mmol}, 1.5$ equiv) was dissolved in THF (50 mL, ?2 mL/g) and cooled in an ice bath. A $1.3 \mathrm{M}$ solution of $i$-PrMgCl. $\mathrm{LiCl}$ in THF (98 mL, $127 \mathrm{mmol}, 1.6$ equiv) was added dropwise over $10 \mathrm{~min}$. The reaction mixture was warmed to 23 ${ }^{\circ} \mathrm{C}$ over $30 \mathrm{~min}$. The resulting solution was added dropwise over $2 \mathrm{~h}$ to a separate reaction vessel cooled to approximately $-50{ }^{\circ} \mathrm{C}$ containing a solution of chiral imine $\mathbf{1 6}$ ( $22 \mathrm{~g}, 79 \mathrm{mmol}, 1.0$ equiv) in DCM (793 $\mathrm{mL}, 0.1 \mathrm{M}$ ). The mixture was allowed to warm to $23^{\circ} \mathrm{C}$ over $12 \mathrm{~h}$, then poured into brine $(2 \mathrm{~L})$, and the aqueous layer was extracted with $\operatorname{DCM}(3 \times 500 \mathrm{~mL})$. The combined organic layers were dried $\left(\mathrm{Na}_{2} \mathrm{SO}_{4}\right)$ and concentrated to give an amber oil. The crude material was purified by flash chromatography with $10 \rightarrow 30 \%$ EtOAc/hexane on a medium length column to give $23.1 \mathrm{~g}$ of the chiral aminothiazole $\mathbf{1 7}$ as an amber oil (52.3 mmol, 66\%).

${ }^{1} \mathrm{H}$ NMR $\left(600 \mathrm{MHz}, \mathrm{CDCl}_{3}\right): \delta=7.16(\mathrm{~s}, 1 \mathrm{H}), 4.83-4.77(\mathrm{~m}, 1 \mathrm{H}), 4.66$ $(\mathrm{d}, J=6.4 \mathrm{~Hz}, 1 \mathrm{H}), 4.16(\mathrm{dd}, J=9.8,3.6 \mathrm{~Hz}, 1 \mathrm{H}), 4.08$ (dd, $J=9.9,3.5$ $\mathrm{Hz}, 1 \mathrm{H}), 1.30$ (s, $9 \mathrm{H}), 0.81$ (s, $9 \mathrm{H}), 0.03(\mathrm{~s}, 3 \mathrm{H}),-0.08$ (s, $3 \mathrm{H})$.

${ }^{13} \mathrm{C}$ NMR $\left(150 \mathrm{MHz}, \mathrm{CDCl}_{3}\right): \delta=173,7,125.0,117.3,66.0,59.0,56.3$, 25.6, 22.5, 18.0, -5.5.

HRMS (ESI): $m / z$ calcd for $\mathrm{C}_{15} \mathrm{H}_{29} \mathrm{BrN}_{2} \mathrm{O}_{2} \mathrm{~S}_{2} \mathrm{SiNa}[\mathrm{M}+\mathrm{Na}]^{+}:$463.0515; found: 463.0512

\section{(R)- $N-\{(S)-2-[($ tert-Butyldimethylsilyl)oxy]-1-[4-(trimethylstan-} nyl)thiazol-2-yl]ethyl\}-2-methylpropane-2-sulfinamide (18)

Bromide 17 (2.2 g, $5.0 \mathrm{mmol}, 1$ equiv) was added to a flame-dried, $\mathrm{N}_{2}-$ filled flask and dissolved in toluene $(25 \mathrm{~mL}, 0.2 \mathrm{M})$. Solid $\mathrm{Pd}\left(\mathrm{PPh}_{3}\right)_{4}$ ( $576 \mathrm{mg}, 0.5 \mathrm{mmol}, 0.1$ equiv) and neat $\mathrm{Me}_{6} \mathrm{Sn}_{2}(2.19 \mathrm{~mL}, 10 \mathrm{mmol}, 2$ equiv) were added and the reaction mixture was heated to $100{ }^{\circ} \mathrm{C}$ for $1 \mathrm{~h}$. The mixture was then cooled to $23^{\circ} \mathrm{C}$ and partially concentrated. The remaining residue was loaded directly onto a column and purified by flash chromatography with $10 \rightarrow 20 \%$ EtOAc/hexane to give $1.56 \mathrm{~g}$ of pure stannane 18 as a slightly yellow oil $(2.97 \mathrm{mmol}, 60 \%)$.

${ }^{1} \mathrm{H}$ NMR $\left(600 \mathrm{MHz}, \mathrm{CDCl}_{3}\right): \delta=7.30-7.27(\mathrm{~m}, 1 \mathrm{H}), 4.89(\mathrm{dd}, J=10.0$, $4.2 \mathrm{~Hz}, 1 \mathrm{H}), 4.70(\mathrm{~d}, J=6.1 \mathrm{~Hz}, 1 \mathrm{H}), 4.15(\mathrm{dd}, J=9.7,4.4 \mathrm{~Hz}, 1 \mathrm{H}), 4.07$ (dd, $J=9.7,3.9 \mathrm{~Hz}, 1 \mathrm{H}), 1.29(\mathrm{~s}, 9 \mathrm{H}), 0.80(\mathrm{~s}, 9 \mathrm{H}), 0.39-0.28(\mathrm{~m}, 9 \mathrm{H})$, $0.01(\mathrm{~s}, 3 \mathrm{H}),-0.11(\mathrm{~s}, 3 \mathrm{H})$.

tert-Butyl 2-[2-(2-\{(1S)-2-[(tert-Butyldimethylsilyl)oxy]-1-[(tertbutylsulfinyl)amino]ethyl]thiazol-4-yl)-6-[4-(methoxycarbonyl)thiazol-2-yl]pyridin-3-yl]thiazole-4-carboxylate (19)

Solid chloropyridine 14 (432 mg, 0.99 mmol, 1 equiv), stannane 18 (518 mg, $0.99 \mathrm{mmol}, 1$ equiv), $\mathrm{Pd}_{2}(\mathrm{dba})_{3}(28.4 \mathrm{mg}, 0.05 \mathrm{mmol}, 0.05$ equiv), and CycloJohnPhos (69.1 mg, $0.2 \mathrm{mmol}, 0.2$ equiv) were added to a flame-dried flask and purged with $\mathrm{N}_{2}$. Toluene was added $(10 \mathrm{~mL}$, $0.1 \mathrm{M}$ ) and the reaction mixture was heated to $100{ }^{\circ} \mathrm{C}$ and stirred for $18 \mathrm{~h}$. The mixture was then cooled to $23^{\circ} \mathrm{C}$ and partially concentrated. The crude residue was loaded directly onto a column and purified by flash chromatography with $35 \rightarrow 50 \%$ EtOAc/hexane on a medium length column to give $716 \mathrm{mg}$ of the coupled product 19 ( $0.94 \mathrm{mmol}$, $95 \%$ ) as a pale-yellow foam. 
${ }^{1} \mathrm{H}$ NMR $\left(600 \mathrm{MHz}, \mathrm{CDCl}_{3}\right): \delta=8.41(\mathrm{~d}, J=8.2 \mathrm{~Hz}, 1 \mathrm{H}), 8.38(\mathrm{~d}, J=8.2$ $\mathrm{Hz}, 1 \mathrm{H}), 8.32(\mathrm{~s}, 1 \mathrm{H}), 8.07$ (s, $1 \mathrm{H}), 7.82(\mathrm{~s}, 1 \mathrm{H}), 4.73$ (q, J = $5.0 \mathrm{~Hz}, 1$ $\mathrm{H}), 4.59(\mathrm{~d}, J=5.6 \mathrm{~Hz}, 1 \mathrm{H}), 4.01(\mathrm{~s}, 3 \mathrm{H}), 3.97-3.89(\mathrm{~m}, 2 \mathrm{H}), 1.62(\mathrm{~s}, 9$ H), $1.30(\mathrm{~s}, 9 \mathrm{H}), 0.86(\mathrm{~s}, 9 \mathrm{H}), 0.06(\mathrm{~s}, 3 \mathrm{H}),-0.02(\mathrm{~s}, 3 \mathrm{H})$.

${ }^{13} \mathrm{C}$ NMR $\left(150 \mathrm{MHz}, \mathrm{CDCl}_{3}\right): \delta=171.6,168.9,164.8,161.7,160.1$, 153.0, 150.8, 150.4, 148.3, 148.0, 140.2, 130.3, 129.4, 128.2, 121.5, $119.0,82.1,66.0,56.2,52.5,28.1,27.5,22.5,18.0$

HRMS (ESI): $\mathrm{m} / z$ calcd for $\mathrm{C}_{33} \mathrm{H}_{45} \mathrm{~N}_{5} \mathrm{O}_{6} \mathrm{~S} S \mathrm{Si}[\mathrm{M}]^{+}:$764.2905; found: 764.2094.

tert-Butyl $(4 S, 5 R)-4-\{[(Z)-1-(4-\{[(1 S, 2 R)-1-(4-\{[(S)-1-(4-\{3-[4-($ tertButoxycarbonyl)thiazol-2-yl]-6-[4-(methoxycarbonyl)thiazol-2yl]pyridin-2-yl\}thiazol-2-yl)-2-hydroxyethyl]carbamoyl\}thiazol2-yl)-2-hydroxypropyl]carbamoyl\}thiazol-2-yl)prop-1-en-1yl]carbamoyl\}-2,2,5-trimethyloxazolidine-3-carboxylate (20)

Trithiazolyl pyridine 19 (910 mg, 1.19 mmol, 1 equiv) was dissolved in $\mathrm{MeOH}(6 \mathrm{~mL}, 0.2 \mathrm{M})$ and $4 \mathrm{~N} \mathrm{HCl}$ in 1,4-dioxane $(1.5 \mathrm{~mL}, 5.95$ mmol, 5 equiv) was added and the reaction mixture was stirred at 23 ${ }^{\circ} \mathrm{C}$ for $2 \mathrm{~h}$. After completion, the mixture was diluted with toluene and concentrated $(3 \times 25 \mathrm{~mL})$. The crude residue was used directly in the next reaction without further purification.

The crude amine was dissolved in $\operatorname{DMF}(11.9 \mathrm{~mL}, 0.1 \mathrm{M})$ and the fragment 9 was added ( $800 \mathrm{mg}, 1.31 \mathrm{mmol}, 1.1$ equiv) followed by HATU (498 mg, $1.31 \mathrm{mmol}, 1.1$ equiv) and DIPEA (0.62 mL, $3.57 \mathrm{mmol}, 3$ equiv). The reaction mixture was stirred for $14 \mathrm{~h}$ at $23^{\circ} \mathrm{C}$. The mixture was diluted with $\mathrm{H}_{2} \mathrm{O}(100 \mathrm{~mL})$ and extracted with EtOAc $(3 \times 50$ $\mathrm{mL}$ ). The combined organic layers were washed with aq $3 \mathrm{M} \mathrm{LiCl}(3 \times$ $50 \mathrm{~mL})$, dried $\left(\mathrm{Na}_{2} \mathrm{SO}_{4}\right)$, and concentrated. The crude material was dry loaded on silica gel and purified by column chromatography with $2 \rightarrow$ $6 \% \mathrm{MeOH} / \mathrm{DCM}$ on a long column to give $1.07 \mathrm{~g}$ of fully assembled intermediate 20 as a yellow solid ( $1.07 \mathrm{~g}, 0.94 \mathrm{mmol}$; $79 \%$ over 2 steps); $\mathrm{mp}>200{ }^{\circ} \mathrm{C}$.

${ }^{1} \mathrm{H} \mathrm{NMR}\left(600 \mathrm{MHz}, \mathrm{CDCl}_{3}\right): \delta=8.38(\mathrm{~d}, J=8.1 \mathrm{~Hz}, 1 \mathrm{H}), 8.32(\mathrm{~s}, 1 \mathrm{H})$, $8.28(\mathrm{~d}, J=8.1 \mathrm{~Hz}, 1 \mathrm{H}), 8.13(\mathrm{~s}, 1 \mathrm{H}), 8.07(\mathrm{~s}, 1 \mathrm{H}), 8.04(\mathrm{~s}, 1 \mathrm{H}), 7.98(\mathrm{~s}$, $1 \mathrm{H}), 5.41-5.37(\mathrm{~m}, 1 \mathrm{H}), 5.31(\mathrm{dd}, J=8.8,1.8 \mathrm{~Hz}, 1 \mathrm{H}), 4.76-4.68(\mathrm{~m}, 1$ H), 4.37 (s, $1 \mathrm{H}), 4.05$ (dd, $J=11.6,2.9 \mathrm{~Hz}, 1 \mathrm{H}$ ), 3.85 (dd, $J=11.5,4.1$ $\mathrm{Hz}, 1 \mathrm{H}), 1.85$ (d, $J=6.7 \mathrm{~Hz}, 3 \mathrm{H}), 1.60-1.58(\mathrm{~m}, J=4.5 \mathrm{~Hz}, 12 \mathrm{H}), 1.44$ $(\mathrm{d}, J=6.1 \mathrm{~Hz}, 3 \mathrm{H}), 1.32(\mathrm{~d}, J=6.4 \mathrm{~Hz}, 3 \mathrm{H})$.

${ }^{13} \mathrm{C}$ NMR $\left(150 \mathrm{MHz}, \mathrm{CDCl}_{3}\right): \delta=171.8,168.9,168.8,168.3,167.0$, $165.1,161.8,161.3,160.7,160.6,152.5,150.7,150.6,149.1,148.6$, $148.2,140.3,130.5,129.2,128.5,127.7,124.5,124.0,122.2,119.1$, 95.0, 82.6, 81.5, 68.3, 64.2, 56.3, 52.6, 51.6, 28.3, 28.2, 26.0, 20.1, 19.4. HRMS (ESI): $m / z$ calcd for $\mathrm{C}_{49} \mathrm{H}_{56} \mathrm{~N}_{10} \mathrm{O}_{12} \mathrm{~S}_{5} \mathrm{Na}[\mathrm{M}+\mathrm{Na}]^{+}: 1159.2575$; found: 1159.2572 .

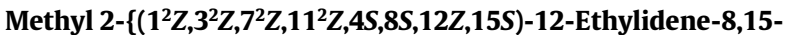 bis[( $R)$-1-hydroxyethyl]-4-(hydroxymethyl)-6,10,14,17-tetraoxo- 5,9,13,16-tetraaza-1(2,4),3,7,11(4,2)-tetrathiazola-2(3,2)-pyridi- nocycloheptadecaphane-2 ${ }^{6}$-yl thiazole-4-carboxylate (21)}

Acyclic precursor 20 ( $1.07 \mathrm{~g}, 0.94 \mathrm{mmol}, 1$ equiv) was dissolved in 3:1 DCM/TFA $(5 \mathrm{~mL})$ and $\mathrm{H}_{2} \mathrm{O}$ was added $(0.5 \mathrm{~mL}, 10 \% \mathrm{v} / \mathrm{v})$. The reaction mixture was stirred at $23{ }^{\circ} \mathrm{C}$ for $2 \mathrm{~h}$. The mixture was concentrated from toluene $(3 \times 20 \mathrm{~mL})$ and the residue was used directly in the next reaction without further purification.

The crude, fully deprotected intermediate was dissolved in DMF (94 $\mathrm{mL}, 0.01 \mathrm{M})$ and HATU ( $715 \mathrm{mg}, 1.88 \mathrm{mmol}, 2$ equiv) and DIPEA ( 0.82 $\mathrm{mL}, 4.70 \mathrm{mmol}, 5$ equiv) were added and the reaction mixture was stirred for $16 \mathrm{~h}$ to completion. The mixture was diluted with EtOAc $(500 \mathrm{~mL})$ and washed with aq $3 \mathrm{M} \mathrm{LiCl}(3 \times 200 \mathrm{~mL})$, dried $\left(\mathrm{Na}_{2} \mathrm{SO}_{4}\right)$, and concentrated. The crude material was purified by column chro- matography with $2 \rightarrow 8 \% \mathrm{MeOH} / \mathrm{DCM}$ on a long column, dry loaded on silica gel. Macrocycle $\mathbf{2 1}$ (233 mg) was collected pure after chromatography as a white solid $(0.25 \mathrm{mmol}, 27 \%$ over 2 steps $)$; $\mathrm{mp}>200{ }^{\circ} \mathrm{C}$.

${ }^{1} \mathrm{H} \mathrm{NMR}\left(600 \mathrm{MHz}, \mathrm{CDCl}_{3}\right): \delta=8.72(\mathrm{~s}, 1 \mathrm{H}), 8.62(\mathrm{~d}, J=8.1 \mathrm{~Hz}, 1 \mathrm{H})$, $8.38(\mathrm{~d}, J=8.1 \mathrm{~Hz}, 1 \mathrm{H}), 8.33(\mathrm{~s}, 1 \mathrm{H}), 8.24(\mathrm{~d}, J=9.2 \mathrm{~Hz}, 1 \mathrm{H}), 8.17(\mathrm{~s}, 1$ $\mathrm{H}), 8.15(\mathrm{~s}, 1 \mathrm{H}), 8.03(\mathrm{~d}, J=8.1 \mathrm{~Hz}, 1 \mathrm{H}), 8.00(\mathrm{~s}, 1 \mathrm{H}), 7.98(\mathrm{~s}, 1 \mathrm{H}), 7.92$ $(\mathrm{d}, J=7.7 \mathrm{~Hz}, 1 \mathrm{H}), 6.43(\mathrm{q}, J=7.0 \mathrm{~Hz}, 1 \mathrm{H}), 5.46-5.39(\mathrm{~m}, 2 \mathrm{H}), 4.89$ (dd, $J=7.8,2.4 \mathrm{~Hz}, 1 \mathrm{H}), 4.70-4.65(\mathrm{~m}, 1 \mathrm{H}), 4.39-4.35(\mathrm{~m}, 1 \mathrm{H}), 4.01$ $(\mathrm{s}, 3 \mathrm{H}), 3.96(\mathrm{dd}, J=11.0,2.9 \mathrm{~Hz}, 1 \mathrm{H}), 1.82(\mathrm{~d}, J=7.0 \mathrm{~Hz}, 3 \mathrm{H}), 1.48(\mathrm{~d}$, $J=6.3 \mathrm{~Hz}, 3 \mathrm{H}), 1.34(\mathrm{~d}, J=6.3 \mathrm{~Hz}, 3 \mathrm{H})$.

${ }^{13} \mathrm{C}$ NMR $\left(150 \mathrm{MHz}, \mathrm{CDCl}_{3}\right): \delta=169.8,168.9,168.8,168.7,166.2$, $165.8,161.8,161.2,161.0,160.4,153.7,150.8,150.6,149.8,149.5$, $148.5,148.2,140.3,130.5,128.9,128.6,128.3,125.1,124.9,123.7$, $121.5,118.9,69.0,67.9,63.7,57.5,54.6,52.6,51.4,20.1,19.0,14.5$.

HRMS (ESI): $m / z$ calcd for $\mathrm{C}_{37} \mathrm{H}_{34} \mathrm{~N}_{10} \mathrm{O}_{9} \mathrm{~S}_{5} \mathrm{Na}[\mathrm{M}+\mathrm{Na}]^{+}: 945.1006$; found: 945.1011 .

\section{Funding Information}

We would like to thank the NIH/NCI Training Grant (T32 CA009523) and UC San Diego for funding this project.

\section{Acknowledgment}

We would like to thank Dr. Brendan Duggan for NMR experiment assistance and analysis. NMR spectra were collected at the UCSD Skaggs School of Pharmacy and Pharmaceutical Sciences NMR Facility.

\section{Supporting Information}

Supporting information for this article is available online at https://doi.org/10.1055/s-0040-1706478.

\section{References}

(1) https://www.cdc.gov/drugresistance/ (accessed Sept. 29, 2020).

(2) (a) Tanaka, T.; Endo, T.; Shimazu, A.; Yoshida, R.; Suzuki, Y. J. Antibiot. 1970, 23, 231. (b) Endo, T.; Yonehara, H. J. Antibiot. 1978, 31, 623 .

(3) Cundliffe, E.; Thompson, J.J. Gen. Microbiol. 1981, 126, 185.

(4) Haste, N. M.; Thienphrapa, W.; Tran, D. N.; Loesgen, S.; Sun, P.; Nam, S. J.; Jensen, P. R.; Fenical, W.; Sakoulas, G.; Nizet, V.; Hensler, M. E. J. Antibiot. 2012, 65, 593.

(5) Benazet, F.; Cartier, M.; Florent, J.; Godard, C.; Jung, G.; Lunel, J.; Mancy, D.; Pascal, C.; Renaut, J.; Tarridec, P.; Theilleux, J.; Tissier, R.; Dubost, M.; Ninet, L. Experientia 1980, 36, 414.

(6) Cromwell, G. L.; Stahly, T. S.; Speer, V. C.; O'Kelly, R. J. Anim. Sci. 1984, 59, 1125.

(7) (a) Just-Baringo, X.; Albericio, F.; Alvarez, M. Marine Drugs 2014, 12, 317. (b) Bagley, M. C.; Dale, J. W.; Merritt, E. A.; Xiong, A. Chem. Rev. 2005, 105, 685. (c) Hughes, R. A.; Moody, C. J. Angew. Chem. Int. Ed. 2007, 46, 7930.

(8) Just-Baringo, X.; Albericio, F.; Alvarez, M. Angew. Chem. Int. Ed. 2014, 53, 6602.

(9) Donia, M. S.; Cimermancic, P.; Schulze, C. J.; Wieland Brown, L. C.; Martin, J.; Mitreva, M.; Clardy, J.; Linington, R. G.; Fischbach, M. A. Cell 2014, 158, 1402. 
(10) Kazami, J. O. T.; Watanabe, M.; Kamigiri, K.; Yamaguchi, T.; Tatsuta, K. WO2007049582 A1, 2007.

(11) (a) Acker, M. G.; Bowers, A. A.; Walsh, C. T. J. Am. Chem. Soc. 2009, 131, 17563. (b) Bowers, A. A.; Acker, M. G.; Koglin, A.; Walsh, C. T.J. Am. Chem. Soc. 2010, 132, 7519. (c) Li, C. X.; Zhang, F. F.; Kelly, W. L. Mol. Biosyst. 2011, 7, 82. (d) Li, C. X.; Zhang, F. F.; Kelly, W. L. Chem. Commun. 2012, 48, 558.

(12) Bowers, A. A.; Acker, M. G.; Young, T. S.; Walsh, C. T. J. Am. Chem. Soc. 2012, 134, 10313.

(13) (a) Baumann, S.; Schoof, S.; Bolten, M.; Haering, C.; Takagi, M.; Shin-ya, K.; Arndt, H. D. J. Am. Chem. Soc. 2010, 132, 6973. (b) Zhang, C. W.; Occi, J.; Masurekar, P.; Barrett, J. F.; Zink, D. L.; Smith, S.; Onishi, R.; Ha, S. H.; Salazar, O.; Genilloud, O.; Basilio, A.; Vicente, F.; Gill, C.; Hickey, E. J.; Dorso, K.; Motyl, M.; Singh, S. B. J. Am. Chem. Soc. 2008, 130, 12102. (c) Singh, S. B.; Zhang, C. W.; Zink, D. L.; Herath, K.; Ondeyka, J.; Masurekar, P.; Jayasuriya, H.; Goetz, M. A.; Tormo, J. R.; Vicente, F.; Martin, J.; Gonzalez, I.; Genilloud, O. J. Antibiot. 2013, 66, 599.

(14) (a) Nicolaou, K. C.; Zak, M.; Safina, B. S.; Estrada, A. A.; Lee, S. H.; Nevalainen, M. J. Am. Chem. Soc. 2005, 127, 11176. (b) Nicolaou, K. C.; Safina, B. S.; Zak, M.; Lee, S. H.; Nevalainen, M.; Bella, M.; Estrada, A. A.; Funke, C.; Zecri, F. J.; Bulat, S. J. Am. Chem. Soc. 2005, 127, 11159. (c) Nicolaou, K. C.; Safina, B. S.; Zak, M.; Estrada, A. A.; Lee, S. H. Angew. Chem. Int. Ed. 2004, 43, 5087. (d) Nicolaou, K. C.; Zak, M.; Safina, B. S.; Lee, S. H.; Estrada, A. A. Angew. Chem. Int. Ed. 2004, 43, 5092.

(15) Wojtas, K. P.; Riedrich, M.; Lu, J. Y.; Winter, P.; Winkler, T.; Walter, S.; Arndt, H. D. Angew. Chem. Int. Ed. 2016, 55, 9772.

(16) (a) Bentley, D. J.; Fairhurst, J.; Gallagher, P. T.; Manteuffel, A. K.; Moody, C. J.; Pinder, J. L. Org. Biomol. Chem. 2004, 2, 701. (b) Lu, J. Y.; Arndt, H. D. J. Org. Chem. 2007, 72, 4205. (c) Lu, J. Y.;
Riedrich, M.; Mikyna, M.; Arndt, H. D. Angew. Chem. Int. Ed. 2009, 48, 8137. (d) Lu, J. Y.; Riedrich, M.; Wojtas, K. P.; Arndt, H. D. Synthesis 2013, 45, 1300.

(17) (a) Muller, H. M.; Delgado, O.; Bach, T. Angew. Chem. Int. Ed. 2007, 46, 4771. (b) Lefranc, D.; Ciufolini, M. A. Angew. Chem. Int. Ed. 2009, 48, 4198. (c) Hughes, R. A.; Thompson, S. P.; Alcaraz, L.; Moody, C. J. J. Am. Chem. Soc. 2005, 127, 15644. (d) Aulakh, V. S.; Ciufolini, M. A. J. Am. Chem. Soc. 2011, 133, 5900. (e) Just-Baringo, X.; Bruno, P.; Ottesen, L. K.; Canedo, L. M.; Albericio, F.; Alvarez, M. Angew. Chem. Int. Ed. 2013, 52, 7818. (f) Akasapu, S.; Hinds, A. B.; Powell, W. C.; Walczak, M. A. Chem. Sci. 2019, 10, 1971.

(18) Christy, M. P.; Johnson, T.; McNerlin, C. D.; Woodard, J.; Nelson, A. T.; Lim, B.; Hamilton, T. L.; Freiberg, K. M.; Siegel, D. Org. Lett. 2020, 22, 2365.

(19) White, E. H.; Field, G. F.; McCapra, F. J. Am. Chem. Soc. 1963, 85, 337.

(20) Martinez, V.; Davyt, D. Tetrahedron: Asymmetry 2013, 24, 1572.

(21) Robak, M. T.; Herbage, M. A.; Ellman, J. A. Chem. Rev. 2010, 110, 3600.

(22) Ferreira, P. T.; Maia, H. S.; Monteiro, L. J. Chem. Soc., Perkin Trans. $11999,3697$.

(23) Caron, S.; Do, N. M.; Sieser, J. E. Tetrahedron Lett. 2000, 41, 2299.

(24) Kopp, F.; Wunderlich, S.; Knochel, P. Chem. Commun. 2007, 2075.

(25) LaMarche, M. J.; Leeds, J. A.; Amaral, A.; Brewer, J. T.; Bushell, S. M.; Deng, G.; Dewhurst, J. M.; Ding, J.; Dzink-Fox, J.; Gamber, G.; Jain, A.; Lee, K.; Lee, L.; Lister, T.; McKenney, D.; Mullin, S.; Osborne, C.; Palestrant, D.; Patane, M. A.; Rann, E. M.; Sachdeva, M.; Shao, J.; Tiamfook, S.; Trzasko, A.; Whitehead, L.; Yifru, A.; Yu, D.; Yan, W.; Zhu, Q. J. Med. Chem. 2012, 55, 2376. 